NBER WORKING PAPER SERIES

THE FINANCIAL ACCELERATOR

AND THE FLIGHT TO QUALITY

\author{
Ben Bernanke \\ Mark Gertler \\ Simon Gilchrist
}

Working Paper No. 4789
NATIONAL BUREAU OF ECONOMIC RESEARCH
1050 Massachusetts Avenue
Cambridge, MA 02138
July 1994

We thank Egon Zakrasjek for his tireless work with the $Q F R$ data, Gabriele Galati and Peter Simon for their assistance, and Anil Kashyap for his comments. Financial support from the National Science Foundation and the C.V. Starr Center is acknowledged. This paper is part of NBER's research program in Monetary Economics. Any opinions expressed are those of the authors and not those of the Board of Governors of the Federal Reserve System, or the National Bureau of Economic Research. 


\title{
THE FINANCIAL ACCELERATOR AND THE FLIGHT TO QUALITY
}

\begin{abstract}
Adverse shocks to the economy may be amplified by worsening credit-market conditions-the financial "accelerator". Theoretically, we interpret the financial accelerator as resulting from endogenous changes over the business cycle in the agency costs of lending. An implication of the theory is that, at the onset of a recession, borrowers facing high agency costs should receive a relatively lower share of credit extended (the flight to quality) and hence should account for a proportionally greater part of the decline in economic activity. We review the evidence for these predictions and present new evidence drawn from a panel of large and small manufacturing firms.
\end{abstract}

Ben Bernanke Woodrow Wilson School

Princeton University

Princeton, NJ 08544

and NBER

Simon Gilchrist

Division of Research and Statistics

Mail Stop 61

Boand of Governors of the Federal Reserve System

Washington, D.C. 20551

\author{
Mark Gertler \\ Department of Economics \\ New York University \\ 269 Mercer Street \\ New York, NY 10003 \\ and NBER
}


I. Introduction

A longstanding puzzle In business cycle analys is is that large fluctuations in aggregate economic activity sometimes arise from what appear to be relatively small Impulses. For example, large swings in Investment spending and output have been attributed to changes in monetary pollcy that had very modest effects on long-term real interest rates. Simllarly, the ofl price shocks of the 1970s, supposedly the causes of serlous recessions, actually had relatively small effects on the average firm's production costs and the typical household's budget.

The "small shocks, large cycles" puzzle motivates our paper. We consider one posstble solution to the puzzle, which is that changes in creditmarket conditlons amplify and propagate the effects of Initial real or monetary shocks. It has been argued, for example, that firms and households tend to be financlally overextended and therefore "vulnerable" at cyclical peaks (see, e.g.. Eckstein and SInal (1986)). An adverse shock or the natural end of an economic expansion may therefore worsen financial conditions significantly, Impalring firms' and households' access to credit at the same time that the need for external funds may be rising (for example, to finance unintended Inventory accumulations). The resulting declines in spending or production exacerbate the economic downturn. We refer to the amplification of InItlal shocks brought about by changes in credic-market conditions as the flnanclal acceleracor.

Although there are various ways of rationalizing a financlal accelerator cheoretically, one useful framework is the "principal-agent" view of credit markets, which has been extensively developed In recent years. Section II of our paper brlefly discusses this framework and shows that a financial 
accelerator could be the result of endogenous changes over the business cycle in the agency costs of lending.

Section III turns to the empirical evidence. Testing for the existence of a financial accelerator raises difficult Identification problems. A promising avenue for circumventing these problems is to examine crosssectional implications of the theory. One such implication is that borrowers who face significant agency costs of borrowing in credit markets--consumers and small firms, for example, or firms with weak balance sheets-.are likely to bear the brunt of an economic downturn. In particular, following an adverse macroeconomic shock, these borrowers should experience reduced access to credit, relative to other borrowers (the flight to quality); as a result, they should also reduce their economic activity earlier and more sharply than do others in the economy. Similarly, these same borrowers should be the first to respond when the economy begins an upswing. Focusing on firms (owing to data Imitations), we cite diverse evidence for the flight to quality in credit markets and for the relatively greater effect of downturns on the activity of borrowers more subject to agency costs.

Most of the evidence clted in section III relles on aggregated data or on studies that consider primarily larger, publicly traded firms. Section IV discusses empirical work that draws on the Department of Commerce's Quarterly Flnanclal Report (QFR), which covers a more representative panel of manufacturing firms and is partially disaggregated (by size class). Using size as a proxy for access to credit markets, this work has found that small manufacturing firms experience substantially more procyclical variation in sales, Inventorles, and short-term debt than do larger firms, consistent with the flight-to-quality prediction. This section also presents some new results obtained from the fIrm-level data underlying the published QFR figures: Using 
the firm-level data, we show that previous QFR-based findings are not substantially changed when we control for Industry or split the sample by a proxy for credit market access other than size. We also perform a back-ofthe-envelope calculation that suggests that roughly one-third of the cyclical varlation in the manufacturing sector can be accounted for by the differences between firms that are relatively more constrained in credit markets and firms that are relatively unconstralned.

Although this paper focuses on the propagation of aggregate fluctuations, we note that our work here is part of a much broader Investigation of the role of credit-market imperfections in macroeconomics. For surveys and discussions of varlous aspects of this literature, see Gertler (1988), Bernanke (1993), Kashyap and Ste1n (1993), Calomir1s (1993), and KIng and Levine (1993).

\section{Theory: The Financlal Accelerator}

In this section we briefly review the theoretical underpinnings of the financlal accelerator, beglnning with partial-equilibrium analyses of the lender-borrower relationship and then turning to general-equilibrium models of macroeconomic dynamics. We also discuss how the theoretical constructs map Into real credit-market institutions. Our goal is to present a few simple economic Ideas and to motivate the empirical sections that follow; no attempt Is made to provide an exhaustive survey.

\section{A. Lenders and borrowers}

As we noted in the introduction, a useful framework for thinking about the flnanclal accelerator is the princlpal-agent approach to credit markets. Bullding on breakthroughs in the economics of Imperfect information in the 
1970s, an extensive literature has studied the structure and functioning of credtt markets in sttuations in whlch lenders (princlpals) cannot costlessly acquire Information about the opportunitles, characteristics, or actions of borrowers (agents). This literature has attempted to rationalize many diverse features of credit markets, Including the forms taken by financial contracts (e.g., debt and equity), the existence of financlal Interwedlarles, the Institution of bankruptcy, the posstbllity of credtt rationing, and so on. Partly for this reason, and partly because there is little agreement about what sorts of Informational frictions are most relevant, the varlous models in the literature differ widely in their baslc ingredients and predictions. Nevertheless, several robust results emerge that provide the basis for the financlal accelerator:

First, external finance is more expensive than internal finance, unless the external finance is fully collateralized. The higher cost of external finance reflects the agency cost of lending (the Inevitable deadwelght loss that arises because of asymetric information).

Second, given the total amount of finance required, the premtum on external finance varles inversely with the borrower's net worth, which we define as the sum of his Internal funds (11quid assets) and the collateral value of his llliquid assets.

Finaliy, a fall in the borrower's net worth, by ralsing the premium on external finance and Increasing the amount of external finance required, reduces the borrower's spending and production. Thls last result is the heart of the financlal accelerator: To the extent that negative shocks to the economy reduce the net worth of borrowers (or postefve shocks Increase net worth), the spending and production effects of the Inltial shock will be amplifled. 
The three basic results listed above can be fllustrated by a simple example, based loosely on Klyotakl and Moore (1993): We suppose there are two perlods, 0 and 1. An entrepreneur operates a technology that takes Input in perlod 0 to produce output in perlod 1 . Inputs are of two types: a fixed factor $K$ (already in place) and a varlable Input $x_{1}$. (Think of the fixed factor as land or a structure-a durable Input that has alternative uses.) At the end of perlod 1, the entrepreneur can sell the flxed factor at the market price of $q_{1}$ per unte. The varlable input, which may be thought of as raw materials, labor, or possibly firm-speciflc capital, depreciates fully In use. The price of the varlable Input is normalized to one.

Output in period 1 is $a_{1} f\left(x_{1}\right)$, where $f\left({ }^{*}\right)$ is Increasing and concave and $a_{1}$ is a technology parameter. The entrepreneur begins perlod 0 with gross cash flow from previous production, ${ }_{0} f\left(x_{0}\right)$, and a debt obligation also Inherited from the past, $r_{0} b_{0}$, where $b_{0}$ is past borrowing and $r_{0}$ is the gross real Interest rate on this liablity. An accounting Identity links the entrepreneur's purchases of the varlable Input $x_{1}$ and new borrowing $b_{1}$ :

$$
x_{1}-a_{0} f\left(x_{0}\right)+b_{1}-r_{0} b_{0}
$$

Funds borrowed In perlod 0 and repald In perlod 1 bear a gross real interest rate of $r_{1}$.

The entrepreneur chooses $x_{1}$ and $b_{1}$ In perlod 0 to maxlmize perlod-1 output net of debt repayment. To motivate a role for financial structure, consider the following simple Incentive problem: Following Kiyotaki and Moore's (1993) adaptation of Hart and Moore (1991). suppose that It is costly for the lender to seize the entrepreneur's output in case of default--as might be true, for example, If it is difficult for third parties (such as courts) to 
observe the borrower's activities. However, suppose that it is not costly to enforce a contingency that the ownership of the fixed factor be transferred to the lender if the borrower does not pay his debts; that is, the fixed factor may serve as collateral. Under these assumptions, it is easy to see that the funds provided by the lender in period 0 will be limited by the timediscounted market value of the fixed factor:

$b_{1} \leq\left(q_{1} / r_{1}\right) K$

Because unsecured lending is not feasible in this environment, there is a "collateral-in-advance" constraint on spending on the variable input.

Combining equations (1) and (2) ylelds:

$$
x_{1} \leq a_{0} f\left(x_{0}\right)+\left(q_{1} / r_{1}\right) K-r_{0} b_{0}
$$

Spending on the variable Input cannot exceed the entrepreneur's net worth, equal to the sum of gross cash flow ${ }_{0} f\left(x_{0}\right)$ and net discounted assets, $\left(q_{1} / r_{1}\right) K-r_{0} b_{0}$. If the entrepreneur's net worth is less than the unconstrained optimal value of $x_{1}$, which satisfles $a_{1} f^{\prime}\left(x_{1}\right)-r_{1}$, then the constraint (3) binds.

Although this framework is extremely simple, it lliustrates the key results discussed above. First, when the incentive constraint ( 3 ) binds, the shadow value of an additional unit of internal funds is $a_{1} f^{\prime}\left(x_{1}\right)$, which exceeds the gross real interest rate prevailing in external capital markets, $r_{1}$. Roughly speaking, the marginal value of a dollar outside the firm is less than that of a dollar inside the firm; the difference in marginal values being an Implicit measure of the agency cost of lending. Second, a fall in net 
worth (arising from either a decline in cash flow or a lower value of the collateralizable asset) both Increases the agency premlum, $a_{1} f^{\prime}\left(x_{1}\right) \cdot r_{1}$, and reduces the borrower's spending (for the intermediate input. In this case) and production. The idea that fluctuations in borrowers' net worth lead to fluctuations in real activity is what we wean by the Elnancial accelerator. 1

Equation (3) also 1llustrates several different factors that can Influence net worth and thus the borrower's spending and production levels. As the equation shows, either a decline in gross cash flows $a_{0} f\left(x_{0}\right)$, a fall in asset prices $q_{1}$, or a rise in inftial debt obligations $b_{0}$ acts to reduce net worth and tighten the constraint. If the collateral constraint is not binding, then an increase in the prospective gross real interest rate $r_{1}$ reduces spending through the conventional cost-of-capital effect (that is, an Increase in $r_{1}$ raises the required marginal productivity of the intermediate Input, $a_{1} f^{\prime}\left(x_{1}\right)$, lowering optimsl spending on $\left.x_{1}\right)$. However, If the constraint Is binding, an Increase in $r_{1}$ lowers borrower spending solely by reducing asset values $\left(q_{1} / r_{1}\right)$ and thus the borrower's net worth. 2 An increase in the Interest rate on pre-existing debt, $r_{0}$, also reduces the borrower's spending (think of a firm with floating-rate or short-term debt) because 1 t reduces cash flow net of current interest payments $\left(a_{0} f\left(x_{0}\right)-I_{0} b_{0}\right)$.

The example given here is extreme in that only perfectly secured lending Is feastble and defaults never occur. However, modifying this framework to permit unsecured lending and the posstbility of default--whlle retalning the connection between net worth and spending--1s not difficult. Indeed, these features can be found in many models in the 11terature. For example. In Tounsend's (1979) well-known costly state verification (CSV) framework, the possiblity of costly auditing by the lender supplements the use of collateral as a means of disciplining borrowers. Th1s additional tool may make unsecured 
lending feasible in equilibrium, Implying that defaults occur with some positlve probabllity. As In our Klyotakl-Moore example, in Townsend's CSV model Internal funds are more valuable to the borrower than external funds, because the borrower must compensate lenders for the Ir expected costs of auditing (Interpretable as the expected deadwelght costs of bankruptcy). Further, In the CSV model a rise in the borrower's net worth reduces the cost of external funds (the unsecured portion of the loan and thus expected default costs decline), thereby stimulating his Investment spending.

Another well-known model with simllar properties is Myers and Majluf's (1984) analysis of new equity issues (see also Greenwald, Stiglitz, and Weiss (1984)). In their model, managers' private Information about the quality of Investment opportunitles adds a "lemons premlum" (Akerlof (1970)) to the cost of external finance. If the portion of an Investment that can be financed internally increases, the lemons problem becomes less severe, which reduces the cost of external finance and increases the likellhood that the Investment w111 be undertaken.

\section{B. Macroeconomic dynamics}

Up to this point we have discussed the financlal accelerator in the context of partial-equilibrium models. Loglcally, the next step is to Incorporate a financlal propagation mechanism within a fully articulated model of the business cycle. Unfortunately, this task is formldable, for several reasons. First, it is obvlously necessary that there be lending and borrowing In equilibrlum, whlch requires the modeler to step outside the convenient representative-agent paradigm and to grapple with the complications Introduced by heterogenelty. In partlcular, in any model with a financlal accelerator the distribution of wealth affects the dynamles of the economy in a nontrivial 
way, which complicates the calculation of the equilibrium. Second, it is desirable to motivate the financial structure from first principles.

Financial contracts and institutions are endogenous, so that results that hinge on arbitrary restrictions on financial structure are suspect. These two considerations make it difficult to develop theoretical frameworks that are both tractable and sufficiently rich to match the data. Nevertheless, a number of articles have presented dynamic general-equilibrium models that feature a financial accelerator, albeit in a relatively stylized way. An example is the 1989 article by Bernanke and Gertler, henceforth B-G. They consider an economy in which firms are financed by Townsend-style (1979) optimal debt contracts. As we discussed above, in the Townsend CSV setup a fall in the borrower's net worth increases the agency premium on external finance; specifically, a highly indebted borrower is more likely to be unable to repay, which triggers costly monitoring by the lender (interpretable as bankruptcy and liquidation). In the B-G economy, an adverse exogenous shock (such as a decline in productivity) lowers current cash flows, which reduces the ability of firms to finance investment projects internally and thus raises the effective cost of investment. The fall in investment spending lowers economic activity and cash flows in subsequent periods, propagating the initial shock (the financial accelerator). B-G show that this mechanism can convert 1.1.d. shocks into autoregressive movements in output. 3

There are several implications of the B-G model that motivate the empirical analysis we present later. First, in their model the dynamics of the cycle are intrinsically nonlinear; more specifically, financial accelerator effects are stronger, the deeper the economy is in recession. This feature arises from the fact that the agency costs of investment faced by a firm become very small or zero as the share of internal finance becomes 
large (a firm with plentiful internal funds pays only a small premium to compensate lenders for bankruptcy risk). Thus, in an economy with sufficient Internal finance, 1.1.d. fluctuations in current profits have no effect on Investment spending, and the financial propagation mechanism disappears. In contrast, fluctuations in profits have large effects on spending when internal finance is already low.

A second Implication is the eflight-to-quality" phenomenon to which we alluded in the introduction. In the B-G model, lenders have access to an alternative Investment technology that pays a safe, fixed return. When prospective agency costs of lending (In the form of bankruptcy risks) increase, lenders reduce the amount of credit extended to firms that require monitoring and invest a greater share of their savings in the safe alternative. 4 It is stralghtforward to extend the arguments to motivate a reallocation of credit in downturns from low-net-worth to high-net-worth borrowers (see, e.g., Bernanke and Gertler (1990) and Calomiris and Hubbard $(1990))$.

For simplicity, B-G use an overlapping-generations framework in which financial contracts necessarily last only one period. Gertler (1992) demonstrates that qualitatively stmilar results emerge when borrowers and lenders contract for multiple perlods. A new finding in Gertler (1992) is that, with multi-period relationships, expected future profits of the borrower can partially substitute for internal finance in reducing agency costs. Because an Increase in the safe real interest rate reduces the present value of expected profits, Gertler's result reinforces the point that higher Interest rates worsen the agency problew. Gertler's analysis also captures the Idea that if firms are cash-short, they may defer Investment for several periods in order to bulld up adequate liquidity. 
Another simplification made by B-G is that employment is fixed (output changes reflect changes only in productivity and the capital stock). Using a qualitatively similar approach, Greenwald and Stiglitz (1993) model a financlal accelerator effect on employment. In the Greenwald-Stiglitz framework, there is a one-period lag between the use of variable inputs and the production of output. A firm suffering a temporary decline in cash flows. therefore, requires additional external funds to finance variable inputs. Since access to these funds depends on the firm's balance sheet position. there is a tight connection between the firm's financial strength and employment demand. Similar arguments extend to the demand for inventories by firms.

In all of the models of the financial accelerator discussed so far, cyclical movements in firms' net worth arise mainly from changes in cash flow. In the paper that provided the basis for our example earlier in this section, Kiyotaki and Moore (1993) develop a dynamic equilibrium model in which endogenous, procyclical fluctuations in asset prices are the principal source of changes in net worth, credit recelved, and spending. ${ }^{5}$ In their model, as In Hart and Moore (1991), lenders cannot force borrowers to repay debts unless those debts are secured. Thus borrowers' assets such as land serve both as factors of production and as collateral for new loans. In this economy a temporary shock (to productivity for example) lowers the value of existing collateral, which tightens borrowing constraints and reduces spending. The fall in spending further lowers the value of existing assets, causing another round of reduced borrowing and spending (note the resemblance to Fisher's (1933) debt-deflation story). Thus the initial shock is propagated through time. 
There is also an interesting potential link between the Idea of the financial accelerator and the large literature on macroeconomic complementarities and multiple equilibria (see Cooper and John (1988)). This Ink may arise because, In an economy with spillovers, an Individual borrower's net worth depends on strateglc Interactions among agents. A recent paper by Lamont (1993) nicely Illustrates this Idea. Lamont considers a situation in which firws' debts Inherited from a previous period create possible "overhang" effects on Investment, 1.e., with high outstanding debts firms may be less willing to invest, since the profits they earn are shared with senior creditors. Using a simplified version of Kiyotaki's (1988) framework, Lamont constructs an example in which the existence of debt overhang leads to the possibility of a low-output expectational equilibrium, an "extra" equilibrium that does not exist if there are no initial debts. He Interprets this result as supporting the Idea that weak balance sheets (high leverage) make the macroeconomy vulnerable to a recession induced by collective pessimism.

Although these theoretical treatments differ on various dimensions, they share the Implication that, In the analysis of macroeconomic dynamics, balance sheet indicators should be thought of as state variables. That is, financial conditions, as well as more conventional factors such as tastes and technology, matter for cyclical behavior. 6

C. The map between theory and practice

How well do the stylized models of lender-borrower relationships that provide the core of the financlal accelerator Idea conform to real Institutions and financial arrangements? The answer depends somewhat on the particular set of actors one has in mind. For the case in which the 
prospective borrower is a small or medium-sized firm, the fit of reality with theory seems reasonably good. Smaller firms, particularly those that are owned primarily by their operators or by a small number of shareholders, correspond well to the typical model's characterization of a borrower as a single entrepreneur seeking to fund an Idlosyncratic project. It is evident also that credit extension to smaller firms involves overcoming Important problems of asymetric Infoxmation; Indeed, almost all credit recelved by smaller companies is intermediated (e.g., by banks, finance companies, or private placements), suggesting the need for specialists in overcoming Informational barriers.

In the case of small and medium-sized fixms, the Implications of Information-based theories also $f$ it well with the observed structure of financlal contracts. Bank loans or privately-placed debt, for example, contain a varlety of covenants relating to required levels of collateral, ratios of working capital to assets, maximum payments of dividends, and so on. Similarly, lines of credit are contingent on to materlal change in financial condition. These features of financial contracts are easily rationalized as mechanisms for mitigating adverse selection and moral hazard problems that arise when Information is Imperfect. Indeed, one can see from these contracts how the financlal accelerator might work in practice: A weakening of a firm's Income statement or balance sheet that brings it in violation of standard financial ratio requirements, or a fall in asset values that reduces its ability to post collateral, has a direct effect on the firm's access to credit and the Interest rate it must pay. Note also the potential nonlinearity of balance sheet effects: Changes in the financial condition of firms that are well above standard requirements have a smaller effect than changes in the financial condition of firms closer to the margin. 
Overall, for small and medium-slzed firms, the Implications of the princlpal-agent approach are close to those of the popular "pecking-order" theory of corporate finance (Myers (1984), Fazzar1, Hubbard, and Petersen (1988)). According to this theory, firms treat internal funds as the cheapest form of finance; If forced to use external finance, they prefer debt (particularly intermediated debt, In some versions) to outside equity. This description of capital structure decisions is consistent with the financial accelerator, since recesslons are likely to reduce both firms' Internal finance and thelr "debt capacity", thereby raising the shadow cost of new Investment.

The mapping of the simple Information-based theorles to large, publiclyheld firmg is less direct. The key question is, Should the retained earnings of the fIrm, which are largely owned by "outsiders" (e.g., small shareholders), be treated as internal or external finance? In practice, managers and directors typlcally exercise considerable discretion over the flrm's retained earnings (or, perhaps, retalned earnings over and above some required dividend level), and so 1 t seems most natural to treat these funds as "Internal", at least over the medium-term horizon. This view is consistent wth both the pecking-order description of firw financing practices and with the somewhat different perspective put forth by Jensen (1989), who also argues that managers control retalned earnings. 7 If we treat retalned earnings as Internal finance, then it appears that large firms may also fit Into the princlpal-agent and be potentially subject to financlal accelerator effects. However, presumably it is also true that large firms-because of the ir greater diversification and longer track records, and because of economies of scale in collecting and processing Information about their situation-have lover agency costs per dollar of external finance than smaller flrms. Thus large, 
publicly-traded firms are likely to do relatively better in domturns and be less exposed to the financial accelerator than are small firms (we discuss the evidence on this polnt below).

Although our focus in this paper is on borrowing by firms, there are of course other important classes of private borrowers. Banks and other Intermediaries must borrow most of the funds that they lend or invest ${ }^{8}$, and despite the existence of deposit insurance the terms at which a bank can borrow may be affected by Its balance sheet. For example, a drop In bank capital may constrain the size of the bank's operations by raising its cost of uninsured funds and through regulatory constraints. Bernanke and Gertler (1987) present a macroeconomic model in which fluctuations in bank capital have aggregate real effects; and much recent empirical work has Investigated the link between bank capital and bank lending (Bernanke and Lown (1991), Peek and Rosengren (1992)). In related research, Kashyap and Stein (forthcoming) find that monetary policy differentially affects the balance sheets and lending capacities of small and large banks, presumably because small banks face higher agency costs of raising uninsured funds.

Households are the other significant category of borrowers. Household borrowers seem reasonably well-described by the principal-agent paradigm (there 1s a particularly good fit with the "collateral-In-advance" model of Hart and Moore (1991)), and some empirfcal work has Indicated that the state of household balance sheets may play a role in the cycle (Important early articles are Mishkin (1977, 1978)). Further, some major household purchases. notably housing, are linked to the condition of household balance sheets by features such as down payments, up-front transactions costs, and Income requirements. A complete description of the financial accelerator mechanisu 
will likely include significant roles for non-firm borrowers such as banks and households.

III. Evidence: The Flight to Quelity

What is the empirical relovance of the financial accelerator for macroeconomic dynamics? Answering this question requires that we come to grips with some difficult identification problems. In particular, analysis of the lead-lag relations between aggregate output and aggregate credit, while perhaps suggestive, is not likely to help us distinguish the financial accelerator theory from alternative approaches.

For example, although the Bernanke-Gertler (1989) framework discussed in the previous section ascribes all persistence of output to the financial accelerator, a correctly-done variance decomposition of data from the Bernanke-Gertler model would imply that 100 of the variance of output arises from productivity shocks (the financial accelerator affects only the shape of output's dynamic response). Also, because in practice corporate cash flows are highly procyclical, there is likely to be a countercyclical demand for short-term credit to finance unintended inventory buildup and other fixed obligations; as a result, even if credit plays a role in cyclical dynamics, it may lag rather than lead the cycle (see Kiyotaki and Moore (1993) for a formalization of this point). On the other hand, a finding that credit leads output can be generated by a model in which credit responds passively to expected production and in which there are no important credit-market Imperfections; see, e.g., King and Plosser (1984). Because theory does not tie down the timing relationships between aggregate output and credit. "horse races" that compare credit and other variables as predictors of output are not likely to be informative about the underlying structure. 
An alternative Identification strategy, which we pursue here, is to look at the cross-sectional Implications of the financial accelerator theory. As we have seen, the theory predicts a differential effect of an economlc downturn on borrowers who are subject to severe agency problems in credit markets and borrowers who do not face serlous agency problems; the difference arises because declines in net worth ralse the agency costs of lending to the former but not the latter. Therefore, If the financlal accelerator is operative, at the onset of a recession we should see a decline in the share of credit flowing to those borrowers more subject to agency costs (the flight to quality $)^{9}$. As a result of their greater cost or difficulty in obtaining credit, these borrowers should reduce spending and production earlier and more sharply than do borrowers with greater access to credit markets. Recessions that follow a tightening of monetary policy are perhaps most 11kely to Involve a flight to quality, because of the adverse effect of Increased Interest rates on balance sheets and because monetary tightening may reduce flows of credit through the banking system (Bernanke and Blinder (1988), Kashyap and Stein (1993)), although this effect should appear to some degree In other recessions as we 11 .

A related implication of the theory is that financlal accelerator effects should be stronger, the deeper the economy is In recession and the weaker the balance sheets of borrowers. ThIs nonlinearity follows from the same theoretical consideration that gives rise to the flight to quality: namely, that changes in net worth may Induce large changes in the agency costs of lending to low-net-worth borrowers, but should not much affect the costs of lending to borrowers with ample Internal finance.

Although cross-sectional tests of the financial accelerator are not without Identification problems of their own, they offer a more promising way 
of distingulshing the flnanclal accelerator from tes alternatives than do tests based on aggregates. As it turns out, the evidence is quite consistent with the prediction that borrowers who face lmportant agency costs in credlt markets are more adversely affected by economlc downturns. In the remalnder of this section we first revlew the evidence on credit flows, then turn to differences in real activity between firms more or less subject to agency costs. New evidence based on a panel of small and large manufacturing firms is presented in Section IV.

A. The flight to quality in credit extension

Disparate pleces of evidence support the hypothesis that, in bad times, credit flows away from borrowers more subject to agency costs. As we discuss below, thls pattern can be observed both directly (In terms of the shares of credic recelved by different classes of borrowers) and Indirectly (In terms of the $m i x$ of Elnanclal instruments through which credit is extended).

Commercial paper versus bank loans. The two dominant forms of shortterm flnance for corporations are commerclal paper and bank loans. In an Important paper, Kashyap, Steln, and Wilcox (1993) examine the behavior of these two types of credit following a tightening of monetary pollcy. The baslc data are provided by our Figure 1: The left colum of the flgure shows the growth rates (log-differences) of commerclal paper outstanding and bank C\&I loans following each of the four Romer dates for whlch the relevant data are avallable. 10 As the flgure Indicates (and as is shown by Kashyap et al.), following a tightening of monetary pollcy there is a sharp increase in commerclal paper issuance, whlle bank loans are flat.

Kashyap et al. Interpret the Increased share of comerclal paper in short-term external finance that follows a monetary tightening as support for 
the bank lending channel of monetary pollcy (Bernanke and Blinder (1988)).

Their suggestion is that monetary tightening limits the supply of bank credit, which forces borrowers to substitute away from bank loans and into comercial paper. A slightly different story, proposed by Gertler and Gilchrist (1993) and Oliner and Rudebusch (1993), explains the KSW fact In terms of the Impact of monetary tightening on the quality mix of borrowers: This alternative story begins with the Idea that there is a countercyclical demand for shortterm credit, which results from declines in firms' cash flows relative to short-term financing requirements (note the Inverse relationship of corporate cash flows and commercial paper issuance in Figure 1). 11 However, although presumably wost firms experience some Increase in their need for short-term credit, they differ in their degree of access to credit markets. In partlcular, high-grade borrowers with access to the commercial paper market obtain funds more easily than lower-quality borrowers who rely primarily on Intermediated credit. As a consequence, commercial paper outstanding rises relative to bank loans subsequent to monetary tightening; this phenomenon reflects a shift in the quality mix of credit and need not be explained by borrowers substituting between loans and paper, as in KSW. However, under elther the substitution or quality mix interpretations, the shift of credit flows in favor of higher-quality borrowers (those that can issue comercial paper) is consistent with the flight-to-quality hypothesis.

Some related evidence is provided in the right column of Figure 1 , which shows the growth rates of real short-term debt for small and large manufacturing firms following the same four Romer dates. 12 Except in 1974. the short-term debt of large firms (who are more likely to be able to issue commercial paper) rose sharply following Romer dates, suggesting that those firms were able to obtain credit to compensate for the decline in internal 
cash flows. In contrast, in none of the eplsodes did small firms (who rarely have access to the commercial paper market) obtain significant additional short-term credit, although presumably they too had increased financing needs. 13

The composition of bank lending. In their study, Kashyap et al. compare the behavior of bank and nonbank sources of credit, finding that an Important nonbank source (commerclal paper) expands relative to bank lending in downturns. However, even when attention is restricted to lending by banks, there is evidence for a flight to quality in recessions or tight-money perlods: For example, Gertler and Gilchrist (1993) and Oliner and Rudebusch (1993) both find that, following Romer dates and controlling for sales, bank loans to small manufacturing firms fall relative to bank loans to large firms (even though, as we have seen, large firms can also satisfy their credit demands by issuing commerclal paper). In a simllar vein, Lang and Nakamura (1992) find that the share of bank loans made above prime (1.e., loans to riskler or haxder-to-monitor borrowers) drops in recessions. Morgan (1993) shows that, following a tightening of monetary policy, firms without previously established lines of credit recelve a smaller share of bank loans; he also notes that declines in noncommitment lending are highly correlated with Increases in the share of the membership of the National Federation of Independent Businesses reporting that credit has become harder to obtain. One more Indication of a flight to quality in bank lending is the behavior of secured (collateralized) versus nonsecured credit. Data from the Federal Reserve's Survey of Terms of Bank Lending Indicates that the share of secured C\&I lending dropped very sharply during the 1981-82 recession ${ }^{14}$, and dropped more modestly prior to the 1990.91 recession, despite 11kely Increases In macroeconomic risk. As has been confirmed by a number of studies (sea, 
e.g., Berger and Udell (1990)), smaller borrowers are much more l1kely to be required to post collateral than larger, more established borrowers. Hence the behavior of secured bank credit suggests once again that during downturns, banks deny loans to weaker borrowers in favor of stronger borrowers. 15 Public versus private bond placements. Finally, turning again to nonbank credit, we can draw an interesting comparison between the rates of Issuance of publicly-offered corporate bonds and private placements. Private placements are bond issues of smaller, less well-known corporate borrowers; bonds issued in private placements are closely held and typically involve a variety of covenants and restrictions on the borrower. Recent research (Corcoran (1992), Carey et al. (1993)) suggests that here, too, there Is a flight to quality, as private placements fall sharply relative to public bond Issues during recesslons and tight-money periods.

B. The effects of the flight to quality on real activity: panel data studies

The financial accelerator fmplies not only that borrowers more subject to agency problems have reduced access to credit during economic downturns, but also that the real economic activity of those firms is differentially affected. A number of panel data studies have addressed this issue.

The template for many of these studies is the Important 1988 paper by Fazzar1, Hubbard, and Petersen (FHP). FHP use data for publicly-traded firms to study the link between Investment spending and cash flow. They divide their sample into groups on the basis of dividend pollcy, arguing (based on considerations of Internal net worth relative to financing requirements) that rap Idly-growing firms not paying dividends are more likely to face external finance constraints than mature, dividend-paying firms. They then regress 
flrms' Investment spending agalnst cash flow measures, Including Tobln's $Q$ In thelr regressions to control for the quality of Investment opportunities. Consistent with the prediction of the financlal accelerator theory, they find that investment is quite sensitive to cash flow for the firms thought most likely a priori to be credit-constralned, and not very sensitive to cash flow for firms that are not expected to be constrained.

Much subsequent work has almost unlversally conflrmed FHP's qualitative flndings. Some of the dimenstons along which the follow-up studles have varled Include the following:

Data sets. FHP's flndings have been supported by studies using several U.S. panel data sets, including a data set drawn from the 1930s (Calomirls and Hubbard (1991)). Studles have also been done for countrles other than the United States, Including Canada (Chlrlnko and Schaller (forthcoming), Schaller (1993)), the United KIngdom (Blundell et al. (1989), Devereux and Schlantarel1i (1990)) and Japan (Hosh1, Kashyap, and Scharfstein (1991)). Sample split criteria. Many articles have followed FHP in Identifying flrms that are likely to be flnanclally constralned by aspects of flrm dividend polfcy. However, a variety of other criterla have been used to split the sample Into flrms subject and firms not subject to significant agency costs, Including firw age, firm size, whether the flrm belongs to a cooperative Industrlal group (Hoshi et al. (1991), ChIrlnko and Schaller (forthcoming)), whether the firm has a bond rating (Whited (1991, 1992)) or is listed on an exchange (011ner and Rudebusch (1992)), ownership structure (Oliner and Rudebusch (1992), Chlrinko and Schaller (forthcoming)), and others. Quite generally, firms that are identified to be financially constrained are also found to exhlbit a greater sensitivity of Investment to cash flow. 
Model specification. The FHP regression of Investment agalnst cash flow and $Q$ is not derlved from a tightly structured model, Following the wellknown article on liquidity constralnts and consumption by Zeldes (1989), a number of studies have attempted to estlmate formally specified models of Investment using the Euler-condition approach, In which explicit allowance is made for the possibility that a finance constraint may be binding (Bond and Meghlr (1994), Gilchrist (1990), Himmelberg (1990), Hubbard, Kashyap, and Whited (1991), and Whited (1992)), Analogous to Zeldes's results for consumers, splits of the sample by financlal crlteria typlcally reveal that flrms identified a priori as facing agency problems in credlt markets differ from the neoclessical benchmark In their Investment behavior, while other flrms do not. Another Interesting result is that the link between firm size and external financial constraints, found by a number of studies, seems to disappear when financial Indicators (such as whether the firm has a bond rating) are controlled for (G1lchrist (1990), Whited (1992)); this finding suggests that financial factors, and not technological factors that may be related to size, explain the observed differences in Investment behavior of smaller and larger firms.

A potential problem with the FHP results is that Tobin's $Q$ may not fully capture the quality of the firm's investment opportunities. If it does not. then cash flow may be correlated with investment not because of internal finance reasons, but because changes in cash flow are informative about future profits. Gilchrist and Himmelberg (1992) allow for this possibility by Including a VAR forecast of future profitabllity (which includes cash flow as a regressor) in the investment equation. They find that investment remains sensitive to cash flow, over and above any sensitivity that might be attributed to the predictive power of cash flow for profits. 
Ocher measures of economic activity. The theory of the financial accelerator predicts that, for firms subject to credit-market constraints, not only capital investment but other types of economic activity should be differentially affected by an economic downturn. This cross-sectional implication has been studied and confirwed for employwent (Cantor (1990), Sharpe (forthcoming)), R\&D spending (Himmelberg and Petersen (1992)), and Inventory Investment (Milne (1991), Sharpe (forthcoming), Kashyap, Lamont, and Stein (1993), and Carpenter, Fazzar1, and Petersen (1993)). The finding that credit-market constralnts are important for Inventory Investment is of particular Interest for macroeconomics, since it may help explain why inventories appear particularly sensitive to cyclical and monetary policy shocks even though there is little evidence of a strong effect of real Interest rates on Inventory demand (Blinder and Maccint (1991)).

Nonlinearity. As we have noted, a related prediction of the theory is that the effects of a change in Internal finance on firms' real economic activity should be greater when the economy is deeper in recession. This prediction has been tested and confirmed in panel data studies by Gertler and Hubbard (1988), who look at the behavior of capital Investment, and by Kashyap, Lamont, and Stein (1993), who examine Investment in Inventories.

IV. Evidence from the Quarterly Financlal Report Although the studies discussed in Section III.B are valuable, the panel data on which they are based have some drawbacks. One shortcoming is that, typically, the firms in the sample are publicly traded companies and therefore are not representative of the general population of firms. Another problem is that, In most cases, the data are avallable only at an annual frequency. 
For these reasons, several studies (Gertler and Gilchrist (1993, forthcoming), Oliner and Rudebusch (1993, 1994)) have employed data drawn from the Quarterly Financlal Report of Manufacturling Flrms (QFR). The advantages of the QFR are that it is comprehensive for the manufacturing sector--1t Includes both companies that are publicly traded and those that are not--and It Is available at the quarterly frequency over a long time period, 1958:Q1 to the present. Potentlally, therefore, the QFR data could be used to study the behavior of the smallest as well as the largest manufacturing firms; to analyze higher-frequency (1.e., quarterly) dynamics; and to assess quantitatively the aggregate Implicationg of credit constralnts and similar phenomena.

A disadvantage of the QFR data is that, unt1l very recently, the only disaggregation of the data avallable was by size class. Thus the studies mentioned above were required to use firm size as a proxy for capital market access and could not directly control for nonfinanclal characteristics of firms that wight be associated with size. However, we have now obtalned the disaggregated, fIrm-level data underlyling the QFR aggregates, for the perlod 1977:Q1 to 1991:Q4 (we are hoping to obtain pre-1977 data at some polnt in the future). In this section we first summarize some findings from previous QFR studles. We then report some results obtalned from the newly-avallable firmlevel deta.

\section{A. Findings from previous QFR studies}

In recent work with the Incompletely-disaggregated QFR data, Gertler and Gilchrist (1993) examine how the response of manufacturing firms to aggregate fluctuations is related to firm size (as measured by firm assets). They combine the elght size classes reported by the QFR Into two categories, 
"small" and "large", defined so that small firms account for 300 of aggregate manufacturing sales on average. The premise of their study is that small firms are more likely to be subject to agency costs of borrowing, so that cyclical differences in the behavior of large and small firms may provide some Indication of the Importance of credit-market imperfections. Indeed, they draw their dividing line between size classes so that firms in the "small" category have characteristics similar to the "constralned" firms in the panel data studies cited in Section III.B. The firms classified as small by Gertler and Gilchrist rely heavily on intermediated credit, obtaining virtually all of their short-term credit from banks, and the largest firms in the small-firm category have capital stocks that are around the median of "constrained" firms In the typical panel data study. In contrast, firms classifled as "large" use the commercial paper market to satisfy roughly half their short-term financing needs, use relatively little bank debt (less than 20\%) and, of course, Include the largest firms in the sector.

An objection to the strategy of using firm size as a proxy for creditmarket access is that size may also be correlated with varlous nonfinancial characteristics, obscuring the interpretation of the results. For example, small firms and large firms are not represented across industries in the same proportions. so that greater cyclicality in the demand for certain types of products may affect small and large firms differentially; we discuss below how controlling for industry membership affects the Gertler-Gilchrist results. More subtly, it may be that, within any given Industry, small firms are the marginal suppliers (elther to the public or to other firms) and so are more vulnerable to declines in industry demand. Still another possibility is that small firms have systematically different (e.g., more flexible or more risky) technologies. To hedge against these potential Identification problems, 
Gertler and Gilchrist look at the cyclical behavior of several different varlables--Including sales, Inventorles, and short-term debt--and perform a varlety of tests on the data. As we discuss below, their results taken together seem easier to reconclle with a credit-based story than with nonfinanclal explanations.

In their analysis Gertler and Gilchrist focus on downturns following tIght money (as measured by Romer dates or Innovations to the Federal funds rate). A first finding is that small-firm sales drop earller and more quickly than those of large firms. Indeed, on average, ten quarters after a Romer date the declines in small-firm sales account for about half of the total drop In manufacturing sales (recall that their average share of sales is 308 ). 16 The greater sensitivity of small-firm sales to the cycle may reflect nonfinanclal factors, as Just discussed. However, there are also Important differences in the behavior of small-firm and large-firm inventorles and short-term debt conditional on sales that are easler to rationalize In the credit-based framework than with alternatives. For example, Gertler and Gilchrist find that, following a tightening of monetary policy, large firms let their Inventory-sales ratio rise for a perlod as sales decline, while small firms firms shed inventories earlier and more rapldly--so wuch so that small-firm inventory-sales ratios fall significantly, despite their relatively greater drop in sales. The difference in the cyclical pattern of inventorysales ratios across size classes is large and statistically significant. The behavior of short-term debt (FIgure 1), much of which is used for Inventory finance and worklng capltal, is consistent with this pattern. Overall, as noted earlfer, larger firms appear able to borrow to carry Inventorles as sales decline, thereby mitigating pressures to reduce production, while small firms are not. In complementary work, Oliner and Rudebusch (1993) find that 
captal investment by small and large manufacturing firms follows a simllar pattern, with small firms cutting back Investment relatively more quickly when cash flows decline. 17

To provide further evidence on whether differences between small and large firms arise from financlal factors, Gertler and Gilchrist apply two other types of tests. First, they look for nonlinear effects (which, as we discussed earlier, are predicted by the theory of the financlal accelerator). They confirm that the effects of monetary pollcy changes on small-firm varlables are greater. when the sector as a whole is growing more slowly. Nonlinearlty is also detected by 01 iner and Rudebusch (1993), who find that cash flow effects on Investment are stronger after perlods of tight money. Second, Gertler and Gilchrist estimate structural inventory equations and find that the ratio of cash flow to Interest expense (a measure of balance sheet quality) is positively related to Inventory accumulation for small firms, but not for large firms. It is not obvious why elther of these results would hold If the differences in small-and large-firm behavior reflected technologlcal or other nonfinancial factors.

\section{B. Results from the fIrm-level QFR data}

Desplte the best efforts of the authors of earller QFR studles, the Incomplete disaggregation of the data placed Inherent limitations on their ability to distingulsh credit-related factors from other factors, such as Industry membership or technology, that differentially affect small and large firms. Using the newly avallable firm-level QFR datal8, we are able to reduce the Identiflation problem by (1) controlling for Industry membership and (2) splitting the sample on criterla other than size. We also use these data to develop rough measures of the aggregate Importance of credit-related effects. 
To control for industrial composition, we first classify firms in our sample as small or large. One of the advantages of the firm-level data is that it is easy to construct these categories based on real asset sizes (the aggregated data are reported by nominal asset size classifications, which requires authors using these data to make complicated adjustments). We group firms into large and small categories based on whether gross assets exceed \$250 million in 1991 dollars. Firms that are "small" by this criterion account for about 30 percent of sales on average, which accords well with the classification used by Gertler and Gilchrist.

Corresponding to the differences in growth rates between small and large firms used in previous studies, we construct industry-adjusted differences as follows: Let $D_{j}$ be the within-industry difference between small and large firms in the growth rate of a variable, ifs the share of the small-firm variable in the industry total, and $w_{f}$ the industry share in the aggregate. Then the industry-adjusted difference in the growth rate between small and large firms, D(IA), is given by

$$
D(I A)-\left(\Sigma_{j} w_{j} w_{j s} D_{j}\right) /\left(\Sigma_{j} w_{j} w_{j s}\right)
$$

Figure 2 plots the cumulated ("leveled-up") values of D(IA) for sales, Inventories, and short-term debt (solid lines). ${ }^{19}$ For comparison, we plot the cumulative differences between small- and large-firm growth rates not adjusted for Industry differences (dashed IInes). Also Indicated in the figure are the dates of cyclical peaks and troughs and the three Romer dates that lie within our sample period.

The figure shows that the differences between the Industry-adjusted and unadjusted series are modest in all cases. In particular, using industry- 
adjusted data, we find as did earlier authors that the sales, Inventories, and short-term debt of small firms fall by considerably more at the beginning of a recession than do those of large firms. Perhaps even more striking is the differentially strong expansion of small firms during the 1982-1985 recovery. Generally, then, the conclusions of earlier studies using incompletely disaggregated $Q F R$ data do not appear to be artifacts of differences in Industry membership between small and large firms.

How Important are the differences between small and large firms, relative to aggregate movements? To address this question in a very rough way, Figure 3 compares the cumulative small-vs-large-firm differences for sales, Inventories, and the inventory-sales ratio (solid Iines) against the corresponding manufacturing sector aggregates (dashed lines). The figure Indicates that the fluctuations in the aggregate variables and in the swall firm-large firm differences are of a similar order of magnitude. As small firms make up approximately one-third of the manufacturing sector in terms of sales, this observation suggests that about one-third of the aggregate cyclical fluctuations can be accounted for by the difference between small and large firms. 20 of course, this estimate ignores a variety of general equilibrium effects and so should not be taken overly serlously. 21 Nevertheless, the number is large enough to motivate further study of the Issue.

Another way that we can use the firm-level data to check the robustness of earlier results is to split the sample by some proxy for credit market access other than size. Figures 4 and 5 report results analogous to Figures 2 and 3, except that the sample is split according to whether a firm is "bankdependent" instead of by size. We use bank-dependency as a criterion because firms that face high agency costs of borrowing are likely to be largely 
rellant on intermediated (as opposed to open-market) forms of credit. We define a bank-dependent firm to be one that has no commercial paper outstanding and has at least 50 of its short-term liabilities in the form of bank loans: these firms account for about 458 of manufacturing sales and Inventorles. All other firms are classifled as non-bank-dependent. Industryadjusted data are shown by the solid lines, unadjusted data by the dashed lines.

Comparison of Figure 4 to Figure 2 shows that classifying firms by financial criterla rather than size does not change the qualitative nature of the results. In particular, although the sales of bank-dependent firms relative to the rest of the sample are somewhat less procyclical than the relative sales of small firms, the behavior of bank-dependent firms' Inventorles and short-term debt is strongly procyclical. Thus, purely technological factors related to size do not appear to explain the findings of earlier studies. (In the future we plan to estimate equations that control for firm size and financlal characteristics simultaneously.) Figure 4 also shows relatively small effects of the Industry adjustments.

Figure 5, which is analogous to Figure 3, plots the differences between bank-dependent and non-bank-dependent f1rm variables agalnst manufacturing sector aggregates. Again, the varlability of the differences between the two classes of firms is comparable to that of the aggregates, or perhaps a bit smaller. As the firms that we have classified as bank-dependent make up about 458 of the manufacturing sector in terms of sales, again a rough estimate of about one-third as the share of aggregate varlability "explained" by financial factors seems appropriate.

Overall, these first results from the fIrm-level QFR data set confirm earlier findings that there are substantial cross-sectional differences 
between borrowers potentially subject to agency costs and those less subject to agency costs. Furthermore. these cross-sectional differences are large enough to be potentially significant in aggregate economic dynamics.

To reinforce this last point, we end this section by noting that.although for data reasons we have focused here on the manufacturing sector-the 1mportance of "small" firms (less than $\$ 250$ million in assets) is generally much greater in other sectors. For example, according to U.S. Dept. of the Treasury (1987), the share of sales by small firms in 1984 was 74.58 in wholesale and retall trade, 87.68 in services, and 89.88 in construction. Thus the 1mplications of credit market Imperfections for the behavior of the economy as a whole may be greater than is suggested by data on the manufacturing sector alone.

\section{v. Conclusion}

The theory underlying the financial accelerator suggests that 1) borrovers facing relatively high agency costs in credit markets will bear the brunt of economic downturns (the flight to quuality); and that 2) reduced spending, production, and Investment by high-agency-cost borrowers will exacerbate the effects of recesslonary shocks. As our paper has discussed, we now have falrly strong evidence--at least for the case of firms--that downturns differentially affect both the access to credit and the real economic activity of high-agency-cost borrowers. It would be useful to Investigate these cross.sectional implications for other sectors, notably the household and banking sectors. Quantification of the 1mportance of the financial accelerator in macroeconomic dynamics is an equally lmportant topic for future research. 


\section{FOOTNOTES}

This example also implies that credit extended to the borrower will fall when borrower net worth falls. More general examples show that credit extensions may elther rise or fall when borrower net worth falls: Although the Increased premium on external finance tends to reduce the amount of credit taken, working in the other direction is the fact that when internal liquidity falls, wore external finance is needed to fund the borrower's fixed obligations such as interest and overhead costs.

2 Farmer (1985) first developed the 1dea that the presence of agency costs may serve to magnify the impact of interest rates on spending.

${ }^{3}$ Aghion and Bolton (1993) give an extensive analysis of dynamics in a related model.

4 An analogous result is obtained by williamson (1987).

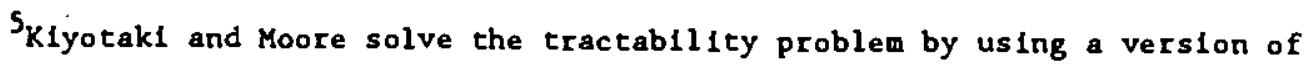
the example given earlier in which it is assumed that the production technology is linear. In this case the collateral constraint always binds, making spending a linear function of borrowers' net worth. This device greatly simplifies aggregation.

${ }^{6}$ This paper emphasizes the role of credit-market factors in the propagation of cycles, as opposed to their initiation; but shocks to credit markets have the potential to Initiate cycles as well. Examples of cyclical impulses arising in credit markets include debt-deflatlonary shocks (Bernanke and Gertler (1990)) and shocks to financial intermediaries (e.g.. bank runs) that disrupt the lending process.

${ }^{7}$ However, Jensen argues that Increased Internal finance lowers rather than increases economic efficiency, since it reduces shareholder control of 
managers and tempts managers to engage in inefficient empire-building.

Although Jensen's views of the link between internal finance and agency costs are just the opposite of the approach taken here, Jensen's theory is consistent with the financial accelerator in a positive sense, as it also Implies that reduced internal finance constrains firm spending.

${ }^{8}$ In some cases, a reasonable interpretation of the canonical principal. agent model is that the bank together with its client borrowers constitute the "borrower" of the model. This interpretation gives primary emphasis to the agency problems that arise between the bank and its creditors or insurers (see Diamond (1984)).

${ }^{9}$ The absolute amount of credit taken by less favored borrowers need not fall, however; see footnote 1 .

$10_{\text {Data }}$ on commerclal paper and bank loans (bank loans, not elsewhere classifled) are from the Flow of Funds and are deflated by the GDP deflator. "Romer dates" are from Romer and Romer (1987) and Indicate times at which. based on a reading of the FOMC minutes, monetary policy is supposed to have tightened. The 1978:3 Romer date is omitted because it is close to the 1979:4 date shown and because it was not followed by a recession.

$11_{A}$ number of papers (Friedman and Kuttner (1993), Gertler and Gilchrist (1993)) have emphasized that there is a countercyclical demand for short-term credit and have shown, in fact, that short-term borrowing in the aggregate tends to rise after monetary tightening. A complementary finding, due to Christiano, Elchenbaum, and Evans (this issue), is that net funds raised by the business sector also increase following a monetary tightening: 1.e., asset accumulation by firms does not offset the rise in gross short-term borrowing.

${ }^{12}$ The data are from the Quarterly Financlal Report, discussed further below. The dividing line between small and large firms (by assets) is drawn 
so that small firms account for about 30 of manufacturing sales on average over the sample. The largest firms in the small-firm category have assets of about $\$ 250$ million In 1992 dollars. See Gertler and Gilchrist (forthcoming).

${ }^{13}$ Gertler and Gilchrist (forthcoming) show that differences in the behavior of small-firm and large-firm debt remaln after controlilng for differences In sales. Gertler and Gilchrist (1993) confirm that trade credit flows from large firms to small firms do not offset the relative decline in small-firm credit.

${ }^{14}$ The fraction of C\&I loans secured by collateral fell from about 50 in 1978 to fust over 20 in 1982.

15 An alternative explanation for the behavior of secured credit is that there is a change over the cycle in the types of loans made, from types that are collateralizable (like Inventory loans) to types that are not. However, the share of loans made above prime that are secured has almost no cyclical sensitivity at all; the major effect appears to be the switch from above-prime borrowers, with high collateralization rates, to below-prime borrowers, with lower collateralization rates.

${ }^{16}$ Note that ten quarters is a sufficient period for supply-side factors to Influence the course of sales. Thus, to the extent that financing constraints Influence small-firm Investment and employwent decialons, they may account for some of the relative decline in sales.

${ }^{17}$ Gertler and GIlchrist emphasized recessions that followed a monetary tightening. However, similar results apply for output fluctuations not directly related to monetary actions.

${ }^{18}$ The data were made avallable to us by the Department of Commerce. The QFR data are based on a compulsory survey and Includes all of the largest firms in each Industry and a stratified sample of smaller firms. 
19 then constructing the Industry-corrected growth rates for small versus large firms (and, simllarly, for bank-dependent and non-bank-dependent flrms below), we computed welghted averages of growth rates across all two-diglt manufacturing Industrles except food and oll. These two Industries are omitted because of the difflculty in correcting for price-level changes in these Industrles, absent two-diglt deflators at the quarterly frequency. All other data are deflated by a common deflator. An analysis of two-digit shlpments prlce deflators at the annual frequency suggests thet this procedure does not introduce serlous blases for non-food, non-01l Industries.

In constructing growth rates for short-term debt we adjusted a large outlier In 1988:3. Th1s outler, although present in the quarterly published reports, could not be matched up with the mlcro data, suggesting the posslbllity of a typographlcal or computational error in data construction.

${ }^{20}$ That is, if small firms behaved like large firms, aggregate fluctuations would be about one-third smaller. An earlier version of the paper contalned more precise calculations (omltted here to save space) of what the aggregate serles would look like if there were no differences between small and large flrms. The results of these calculations are somewhat sensitive to the starting date chosen but were generally consistent with an Importance estimate of one-third.

${ }^{21}$ One general equilibrium effect that would weaken the aggregate Importance of small flrm-large firm differences is output substitution, 1.e., It Is possible that when small firms are forced by restricted access to credit markets to cut production, large flrws quickly make up the lost output. Factors reducing the potentlal for output substitution Include 1mperfec: substitutabllity of flrms' products, lmperfect factor mobllity, and the possibllity that markups rise when product market competition is reduced 
(Chevaller and Scharfstein (1994)). Note also that at lesst half of the small-large differences In Inventory behavior come from differences in movements in Inventory-sales ratios rather than from differences in sales. General equilibrium effects that might lead us to increase our estimate of the Importance of small firms Include aggregate demand splllovers and factor. market 1 Inkages. 
REFERENCES

Aghion, Phllippe and Patrlck Bolton. "A Theory of Trickle-Down Growth and Development with Debt Overhang", unpublished, Nuffleld College (Oxford) and LSE, 1993.

Akerlof, George, "The Market for Lemons: Quality Uncertalnty and the Market Mechanisn", Quarterly Journal of Economlcs, LXXXV, August 1970, 488-500.

Berger, Allen, and Gregory Udell, "Collateral, Loan Quallty, and Bank RIsk", Journal of Monetary Economics, XXV, January 1990, 21-42.

Bermanke, Ben, "Credit In the Macroeconomy", Quarterly Review, Federal Reserve Bank of New York, XVIII, Spring 1993, 50-70.

Bernanke, Ben and Alan Blinder, "Credit, Money, and Aggregate Demand". American Economic Review, LXXVIII, May 1988, 435-39.

Bernanke, Ben and Mark Gertler, "Banking In General Equilibrium", In William Barnett and Kenneth SIngleton, eds. New Aproaches to Honetary Economics, Cambridge, UK: Cambridge University Press, 1987.

Bernanke, Ben and Mark Gertler. "Agency Costs. Net Worth, and Business Fluctuations", American Economic Review, LXXIX, March 1989, 14-31.

Bernanke, Ben and Mark Gertler, "FInanclal Fragllity and Economic Performance", Quarterly Journal of Economics, CV, February 1990, 87-114.

Bernanke, Ben and Cara Lown, "The Credlt Crunch", Brookings Papers on Economic Activity, 1992:2, 205-39.

Blinder, Alan and Louls Maccinl, Taking Stock: A Critlcal Assessment of Recent Research on Inventorles", Journel of Economic Perspectives, V. Winter $1991,73-96$.

Blundell, Rlchard, Stephen Bond, Mlchael Devereux, and Fablo Schlantarell1, "Investment and Tobin's Q", unpublished, Institute for Fiscal Studies, 1989.

Bond, Stephen and Costas Meghlr, "Dynamic Investment Models and the F1rm's Financlal Policy". Review of Economic Studies, LXI, April 1994, 197-222.

Calomirls, Charles, "Financial Factors in the Great Depression". Journal of Economic Perspectives, VII, Spring 1993, 61-86.

Calomirls, Charles and R. Glenn Hubbard, "Imperfect Information, Multiple Loan Markets, and Credit Rationing", Economic Journal, C, January 1990.

Calomirls, Charles and R. Glenn Hubbard, "Tax Pollcy, Internal Finance, and Investment: Evidence from the Undistributed Profits Tax of 1936-1937", unpublished, University of Illinols, September 1991. 
Cantor, Richard, "Effects of Leverage on Corporate Investment and Hiring Decisions", Quarterly Review, Federal Reserve Bank of New York, XV, Summer $1990,31-41$.

Carey, Mark, Stephen Prowse, John Rea, and Gregory Udell, "The Economics of the Private Placement Market", preliminary staff study, Board of Covernors, March 1993.

Carpenter, Robert, Steven Fazzari, and Bruce Petersen, "Inventory (Dis) investonent, Internal Finance Fluctuations, and the Business Cycle", unpublished, Emory University, August 1993.

Chevalier, Judith and David Scharfstein, "Capital Market Imperfectlons and Countercyclical Markups: Theory and Evidence", NBER workIng paper no. 4614, January 1994.

ChIrinko, Robert and Huntley Schaller, "Why Does Liquidity Matter in Investment Equations?". Joumal of Money, Credit, and Banking (forthcoming).

Christlano, Lawrence, Martin Eichenbaum, and Charles Evans, "The Effects of Monetary Policy Shocks: Evidence from the Flow of Funds", Review of Economics and Statistics, this issue.

Cooper, Russell and Andrew John, "Coordinating Coordination Failures in Keynesian Models", Quarterly Journal of Economics, CIII, August 1988, 441-64.

Corcoran, Patrick, "The Credit Slowdown of 1989-1991: The Role of Supply and Demand". Federal Reserve Bank of Chicago, Proceedings of the 28th Annual Conference on Bank Structure and Competition, 1992.

Devereux, Michael and Fablo Schiantarelli, "Investment, Financial Factors, and Cash Flow: Evidence from U.X. Panel Data", In R. Glenn Hubbard, ed., Asymetrlc Information, Corporate Finance, and Investment, Chicago: University of Chicago Press, 1990.

Diamond, Douglas, "Financlal Intermediation and Delegated Monitoring", Review of Economlc Studies, LI, July 1984, 393-414.

EcksteIn, Otto and Allen Sinal. "The Mechanisms of the Business Cycle In the Postwar Era", In Robert J. Gordon. The American Business Cycle: Continulty and Change, Chicago: University of Chicago Press, 1986.

Farmer. Roger, -Implicit Contracts with Asymmetric Information and Bankruptcy: The Effect of Interest Rates on Layoffs", Review of Economic Studies, LII, July $1985,427-42$.

Fazzari, Steven, R. Glenn Hubbard, and Bruce Petersen, "Financing Constraints and Corporate Investment", Brookings Papers on Economic Activity, 1988:1, 141195 .

Fisher, Irving, "The Debt-Deflation Theory of Great Depressions", Econometrica, I, October 1933, 337.57. 
Frledman. Benjamin and Kenneth Kuttner. "Economlc Activity and the Short-term Credit Markets: An Analysis of Prices and Quantitles". Brooklngs Papers on Economic Activicy, 1993:2, 193-284.

Gertler, Mark, "Flnanclal Structure and Aggregate Economlc Activity: An overvlew", Joumal of Money, Credit, and Banking, XX, August 1988 (Part 2), $559-88$.

Gertler. Mark, "Flnanclal Capacity and Output Fluctuations In an Economy with Multiperlod Flnanclal Relationships", Revlew of Economic Studies, LIX, July $1992,455-72$.

Gertler, Mark, and SImon Gilchrist, "The Role of Credit Market Imperfectlons In the Monetary Transmission Mechanism: Argurents and Evidence", Scandinavian Journal of Econowles, 1993, XCV, 43-64.

Gertler. Mark and SImon GIlchrist, "Monetary Pollcy, Business Cycles, and the Behavior of Small Manufacturing FIrms", Quarterly Journal of Economics (for theoming).

Gertler, Mark and R. Glenn Hubbard, "Flnanclal Factors in Business Fluctuatlons*. Federal Reserve Bank of Kansas CIty, Flnanclal Markec Volactlity, 1988.

GIlchrist, SImon, "An Emplrical Analysis of Corporate Investment and Financing Hlerarchles Using FIrm-Level Panel Data", unpublished, Board of Governors, 1990.

Gilchrist, Simon and Charles HImmelberg, "Evidence for the Role of Cash Flow In Investment", unpublished, Board of Governors, 1992.

Greenwald, Bruce and Joseph StIglitz, "FInanclal Market Imperfections and Business Cycles", CVIII, Quarterly Journal of Economlcs, February 1993, 77 114.

Greenwald, Bruce, Joseph StIglitz, and Andrew Welss, -Information Imperfections In the Capltal Market and Macroeconomic Fluctuations", Americen Economlc Revlew, LXXIV, May 1984, 194-99.

Hart, Ollver and John Moore, -A Theory of Debt Based on the Inallenabllity of Human Cap1tal", LSE Financlal Market Group discussion paper no. 129, 1991.

HImmelberg. Charles, Essays on the Relationship Between Investment and Internal Finance", Ph.D. dissertation, Northwestern University, 1990.

HImmelberg, Charles and Bruce Petersen, "R\&D and Internal Finance: A Panel Study of Small Firms in HIgh-Tech Industrles", unpublished, Washington University, 1992.

Hosh1, Takeo, An:l Kashyap, and David Scharfste1n, "Corporate Structure, LIquidity, and Investment: Evidence from Japanese Panel Data", CVI, Quarterly Journal of Economics, February 1991, 33.60. 
Hubbard, R. Glenn, Anll Kashyap, and Tonl Whited, "Internal Finsnce and Firm Investment", unpublished, Columbia University, 1991.

Jensen, Michael, "Agency Costs of Free Cash Flow, Corporate Finance, and Takeovers", American Economic Review, LXXIX, May 1989, 323-9.

Kashyap, An1l, and Jeremy Stein, "Monetary Pollcy and Bank Lending", NBER working paper no. 4317, April 1993.

Kashyap, An1l and Jeremy Stein, "The Impact of Monetary Pollcy on Bank Balance Sheets", Carnegie-Rochester Conference Serles on Publlc Pollcy, forthcoming.

Kashyap, An11, Owen Lamont, and Jeremy Stein, "Credit Conditions and the Cyclical Behavior of Inventories: A Case Study of the 1981-82 Recession", working paper WP-93-7, Federal Reserve Bank of Chicago, 1993.

Kashyap, An1l, Jeremy Stein, and David Wilcox, "Monetary Pollcy and Credit Conditions: Evidence from the Composition of External Finance". American Economic Review, LXXXIII, March 1993, 78-98.

KIng, Robert and Ross Levine, "FInance and Growth: Schumpeter Might Be Right", Quarterly Journal of Economics, August 1993, CVIII, 717-38.

KIng, Robert and Charles Plosser, Money, Credit, and Prices in a Real Business Cycle", American Economlc Revlow, June 1984, LXXIV, 363-80.

Kiyotak1, Nobuhiro, "Multiple Expectational Equllibria Under Monopolistic Competition", Quarterly Journal of Economics, CIII, November 1988, 695-713.

Kiyotak1, Nobuh1ro and John Moore, "Credit Cycles", unpubrished, Univers1ty of Minnesota, March 1993.

Lamont, Owen, "Corporate Debt Overhang and Macroeconomic VulnerabIlity", unpublished, M.I.T., 1993.

Lang. W1111am and Leonard Nakamura, 'Flight to Quality' in Bank Lending and Economic Activity", unpublished, Federal Reserve Bank of Philadelph1a, 1992.

Milne, Alistalr, "Financial Effects on Inventory Investment", unpublished, London Business School, 1991.

Mishkin, Frederic S., What Depressed the Consumer? The Household Balance Sheet and the 1973.75 Recession", Brookings Papers on Economlc Actlvity, $1977: 1,123 \cdot 64$.

Mishkin, Frederic S., "The Household Balance Sheet and the Great Depression", Journal of Economlc HIstory, XXXVIII, December 1978, 918-37.

Morgan, Donald, "The Lending Vlew of Monetary Policy and Bank Loan Commitments". Federal Reserve Bank of Kansas City, unpublished, November 1992; last revision, July 1993.

Myers, Stewart, "The Capital Structure Puzzle", Joumal of Finance, XxxIX, July 1984, 575-92. 
Myers, Stewart and Nicholas Majluf, "Corporate Financing and Investment Decisions When Firms Have Information That Investors Do Not Have", Journal of Financlal Economles, XIII, June 1984, 187-221.

Oliner, Stephen and Glenn Rudebusch, "Sources of the Financing Hierarchy for Business Investment and Agency Costs", Revlew of Economics and Statistics, LXXIV, 1992, 643-53.

Oliner, Stephen and Glenn Rudebusch, "Is There a Bank Credit Channel to Monetary Pollcy?", unpublished. Board of Governors. 1993.

oliner, Stephen and Glenn Rudebusch, "Is There a Broad Credit Channel to Monetary Pollcy?", unpublished, Board of Governors. 1994.

Peek. Joe and Eric Rosengren, "The Capital Grunch in Neu England", Federal Reserve Bank of Boston, New England Economic Revlew [Ed: no vol, number]. May/June 1992, 21-31.

Romer, Christina and David Romer, "Does Monetary Pollcy Matter? A New Test in the Splrte of Friedman and Schwartz", NBER Macroeconomles Annual, 1989, 121. 70 .

Schaller. Huntley, "Asymetric Information, Liquidity Constralnts, and Canadian Investment". Canadian Journal of Economles, XXVI, August 1993.

Sharpe, Steven, "Financlal Market Imperfections, F1rm Leverage, and the Cyclicality of Employment". American Economic Review, forthcoming.

Townsend, Robert, "Optimal Contracts and Competitive Markets with Costly State Verification", Journal of Economlc Theory, XXI, 1979, 265-93.

U.S. Department of the Treasury, Internal Revenue Service, Statistics of Income: Active Corporation Income Tax Returns, Washington: GPO, 1987.

Whited, Ton1, "Investment and Financial Asset Accumulation", Journal of Financlal Intermediation, 1, December 1991, 307-34.

Whited, Ton1, "Debt, Liquidity Constraints, and Coxporate Investment: Evidence from Panel Data", Journal of Finance, XLVII, September 1992, 1425-60.

Williamson, Stephen, "Costly Monitoring, Optimal Contracts, and Equilibrium Credit Rationing", Quarterly Journal of Economics, CII, February 1987, 135-46.

Zeldes, Stephen, "Consumption and Liquidity Constraints: An Empirical

Investigation", Journal of Political Economy, XCVII, Aprł1 1989, 1196-1216. 
Figure 1: Behavior of Short-Term Debt Aggregates and Corporate Earnings Around Romer Episodes of Tight Money

Commercial Paper, C\&l Loans. and Corporate Earnings
Short-Term Debt of Manufacturing Firms

$1968: 4$
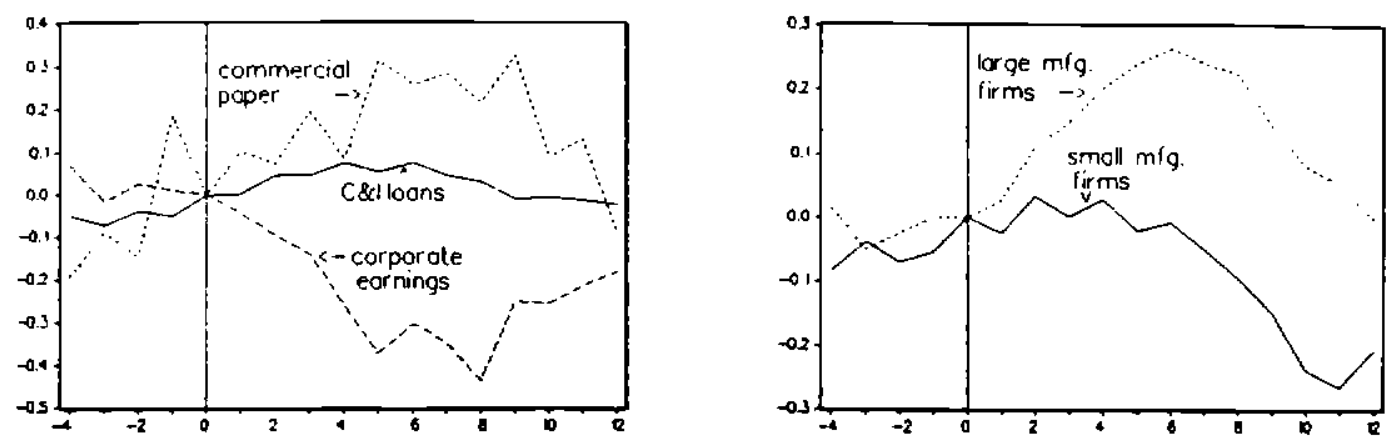

$1974: 2$
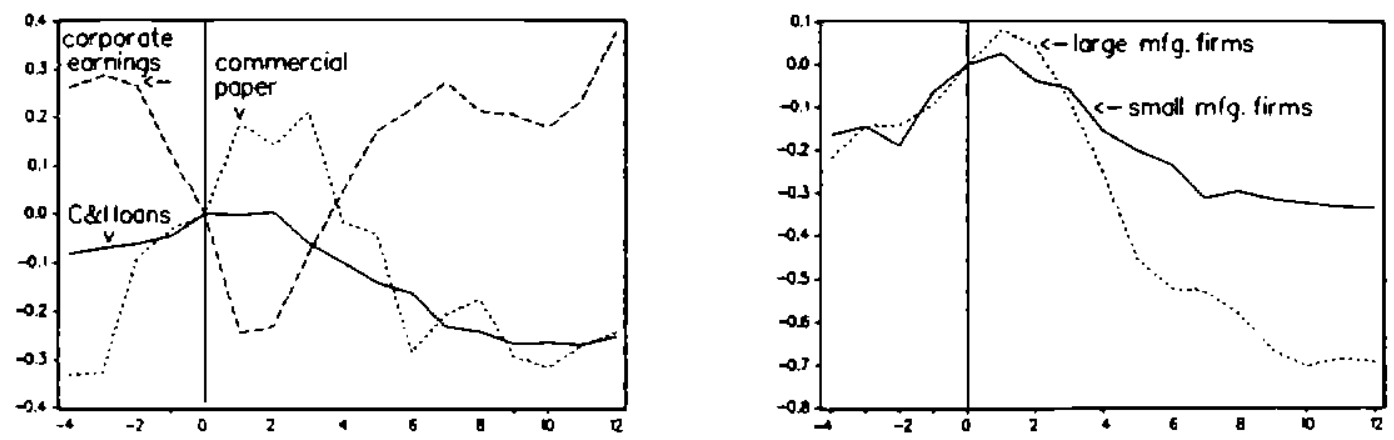

Notes: The panels on the left plot the percentage change of non-financial commercial paper, C\&l in.e.c.) loans, and corporate earnings around two of the five last Romer episodes of tight money. We exclude 1978:3 since the panet on 1979:4 conveys most of the information. The data are from flow of Funds and Ciribase. The panels on the right plot the percentage change in short term debt for large and small manufacturing firms. The data are constructed from the Quarterly Financial Report. See Gertler and Gilchrist (1992). All series are detrended and in real terms. 
Figure 1 (cont.): Behavior of Short-Term Debt Aggregates and Corporate Earnings Around Romer Episodes of Tight Money

Commercial Paper, C\&l Loans, and Corporate Earnings
Short-Term Debt of Manufacturing Firms

$1979: 4$

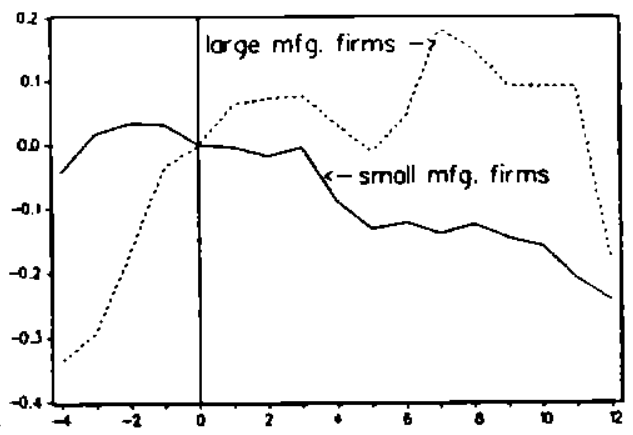

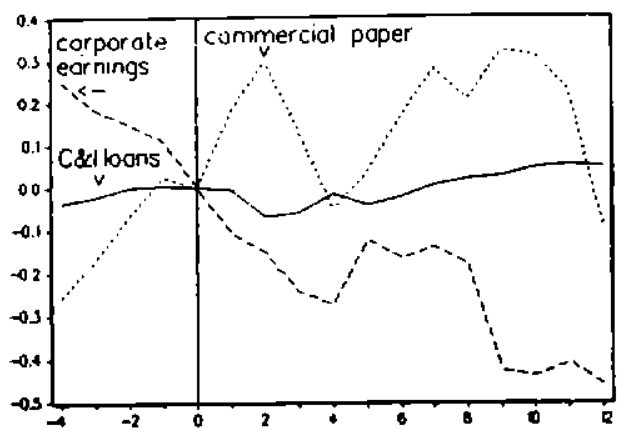

1988:4

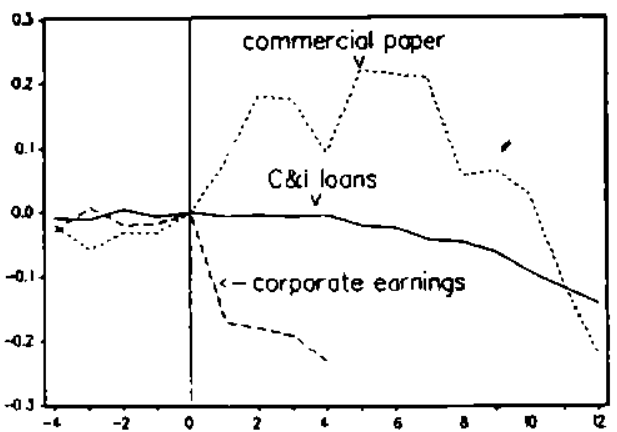

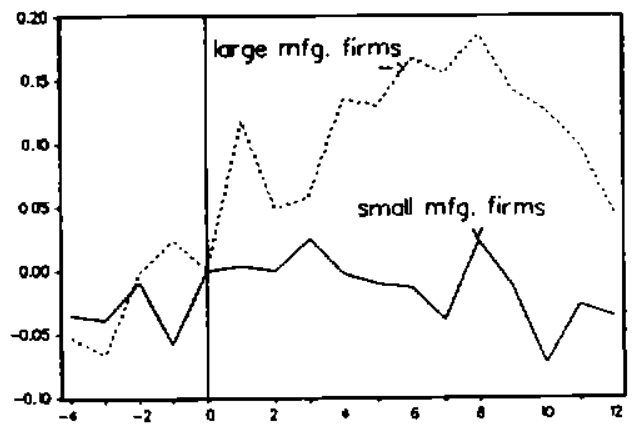


Figure 2: The Difference between Small and Large Firm Cumulative Growth Rates:

A Comparison of Industry-Adjusted vs. Unadjusted Data.

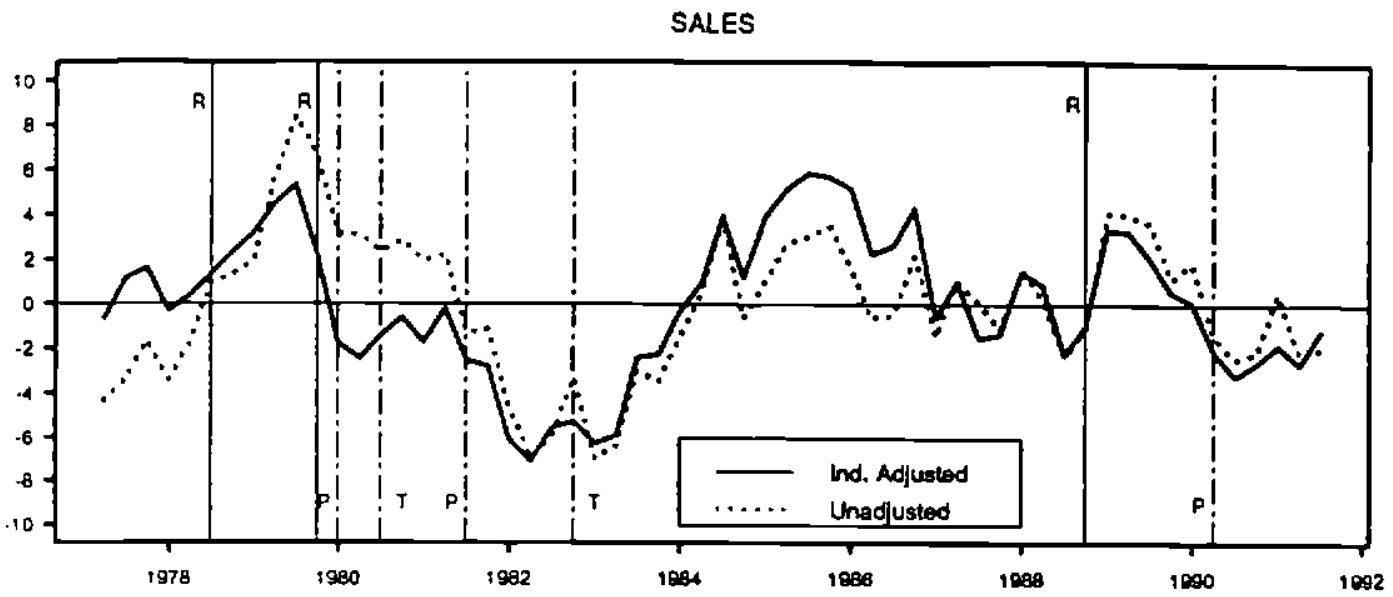

INVENTORIES

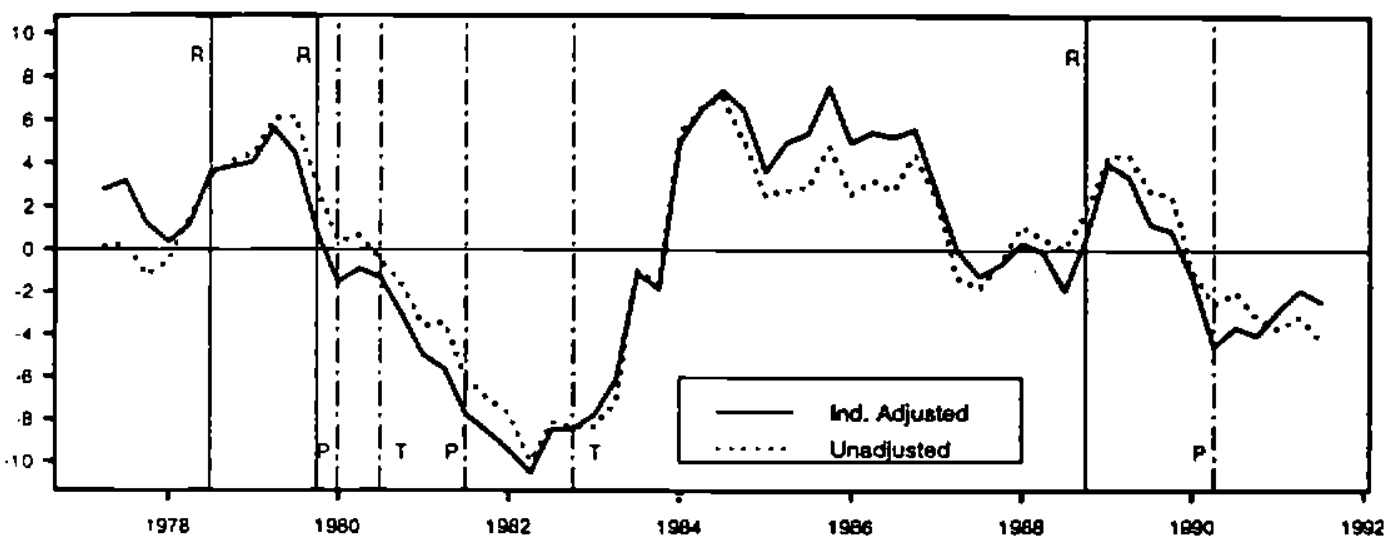

SHORT DEAT

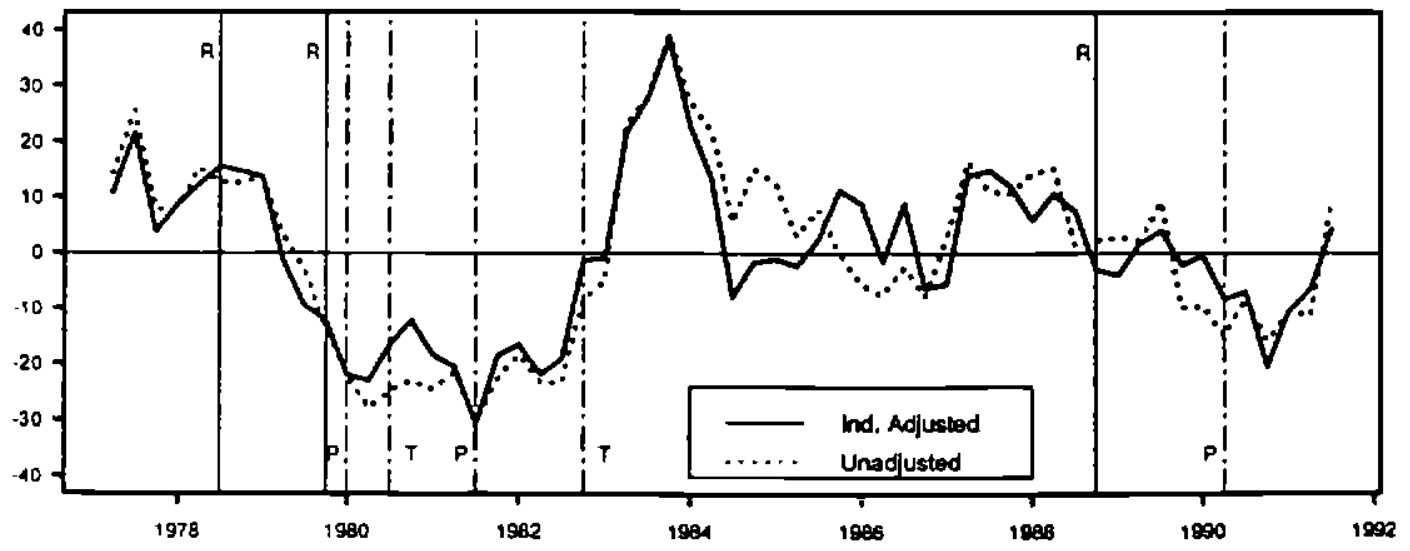


Notes to FIgure 2:

Industry-adjusted data welghts the difference In growth rates between small and large firms by the small-firm share in each industry. The resulting growth rates are cumulated and a quadratic trend is removed. Small firms are defined to be those with assets less than $\$ 250$ million In 1991 dollars.

R: Romer date, P: NBER business cycle peak, $T$ : NBER business cycle trough. 
Figure 3: The Difference between Small and Large Firm Cumulative Growth Rates:

A Comparison with the Cumulative Growth Rate of Total Manufacturing.

SALES

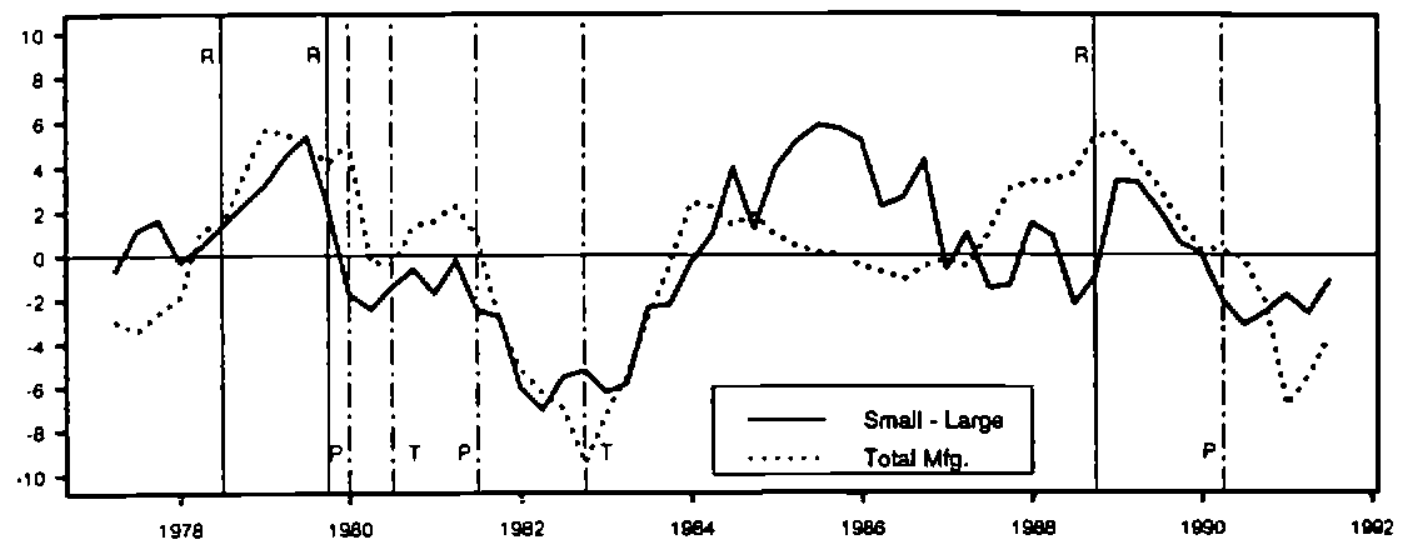

INVENTORIES

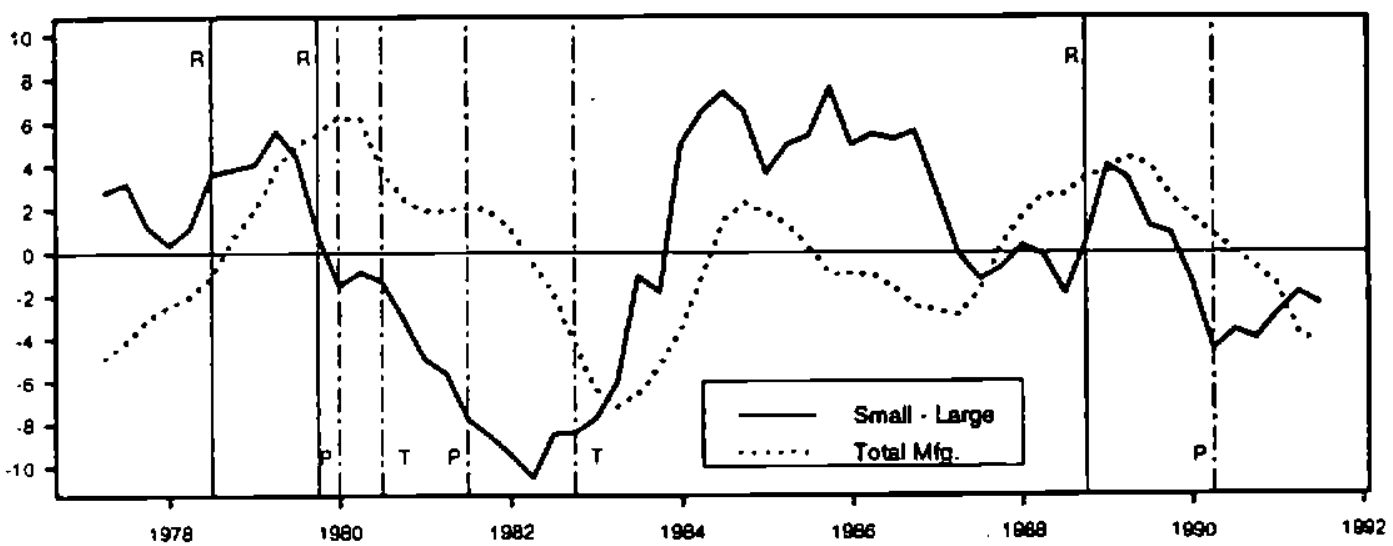

INVENTORIES/SALES

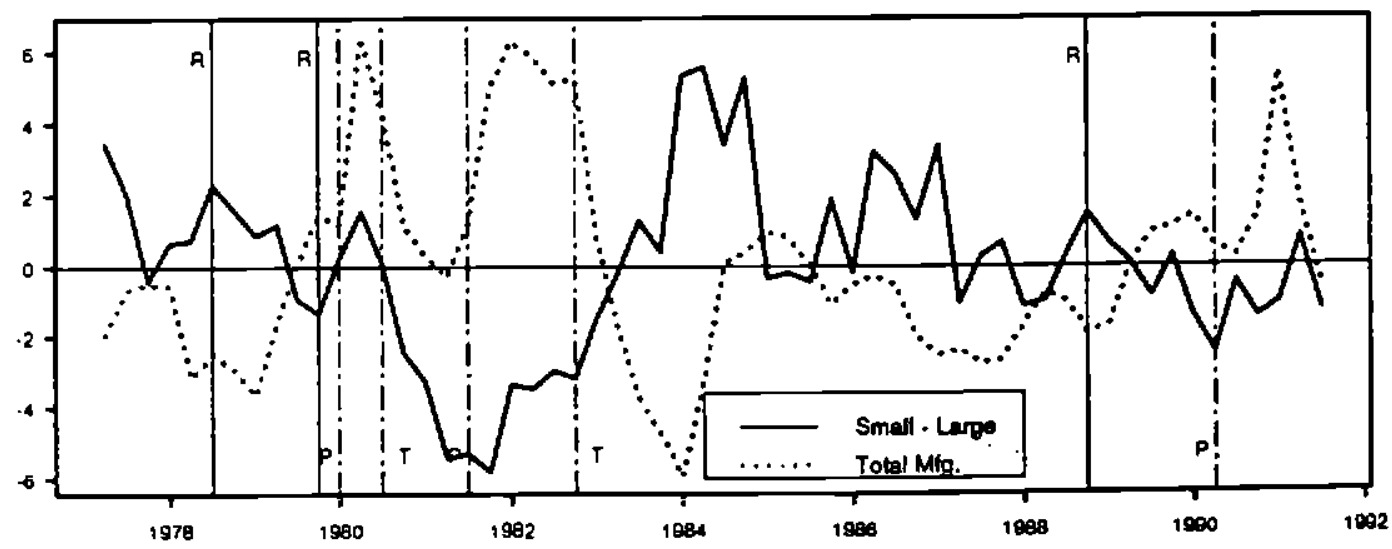


Notes to Figure 3 :

See notes to Figure 2. Differences in growth rates between small and large firms are Industry-adjusted. 
Figure 4: The Difference between Bank-Dependent and Non-Bank-Dependent Firms:

A Comparison of Industry-Adjusted vs. Unadjusted Data.

SALES

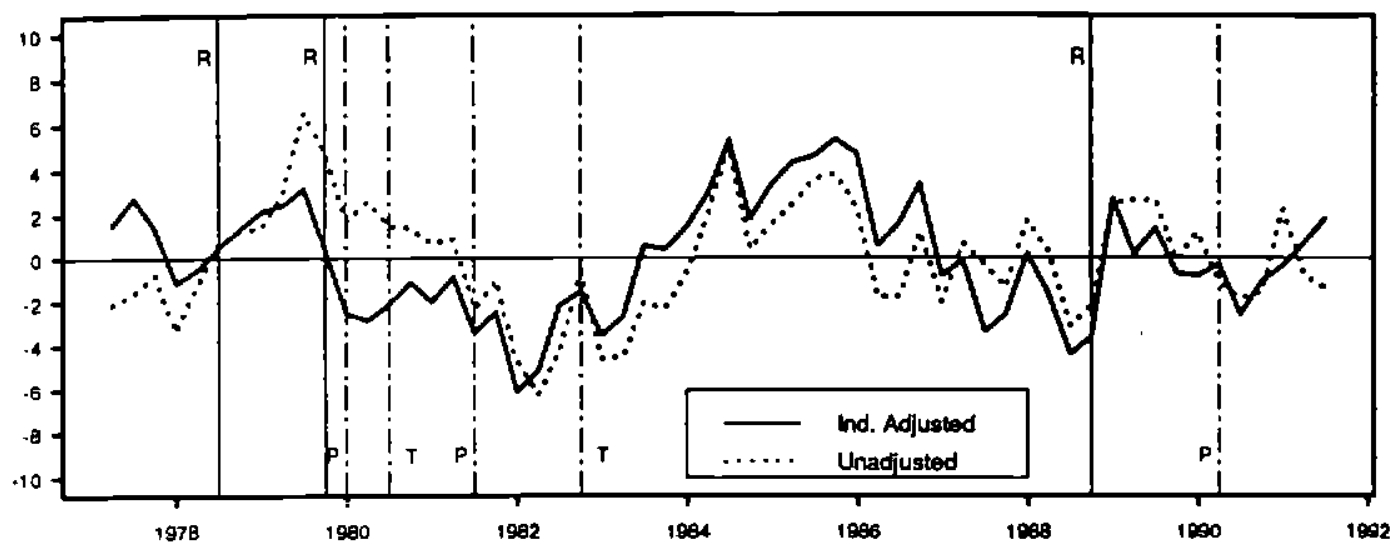

INVENTORIES

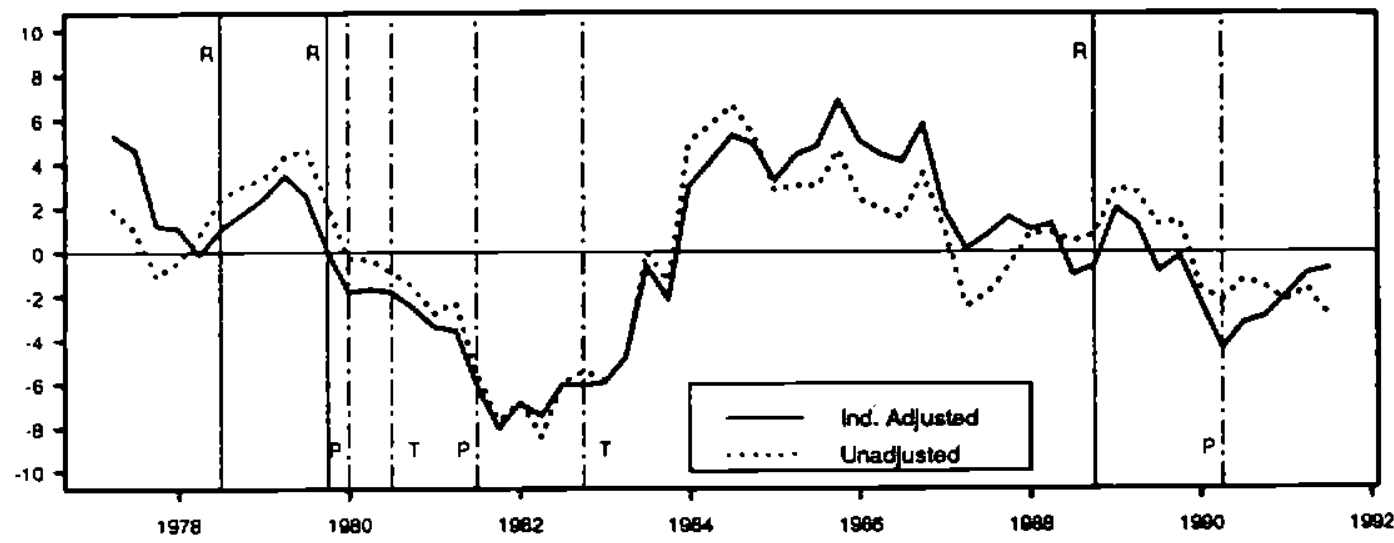

SHORT DEET

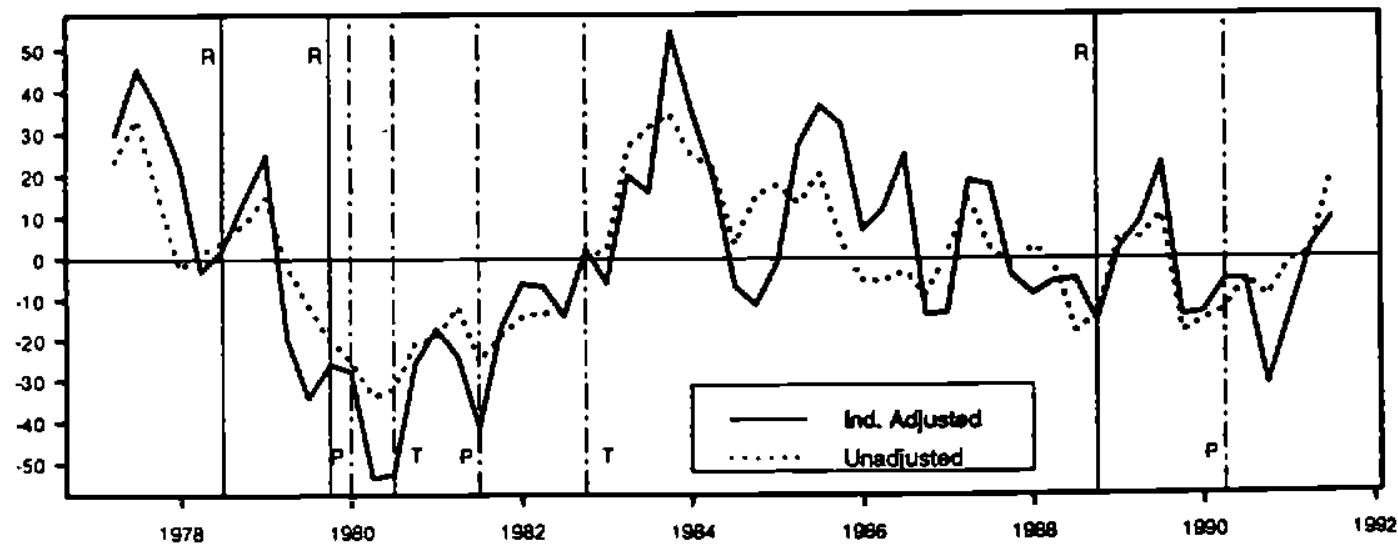


Notes to F1gure 4:

The flgure is analogous to $F 1$ gure 2, except that firms are

classifled by "bank-dependency" rather than asset slze. Bank-dependent flrms are defined as firms with a ratlo of bank debt to short-term debt greater than 0.5 and with no commerclal paper outstanding. 
Figure 5: The Difference between Bank-Dependent and Non-Bank-Dependent Firms:

A Comparison with the Cumulative Growth Rate of Total Manufacturing.

SALES

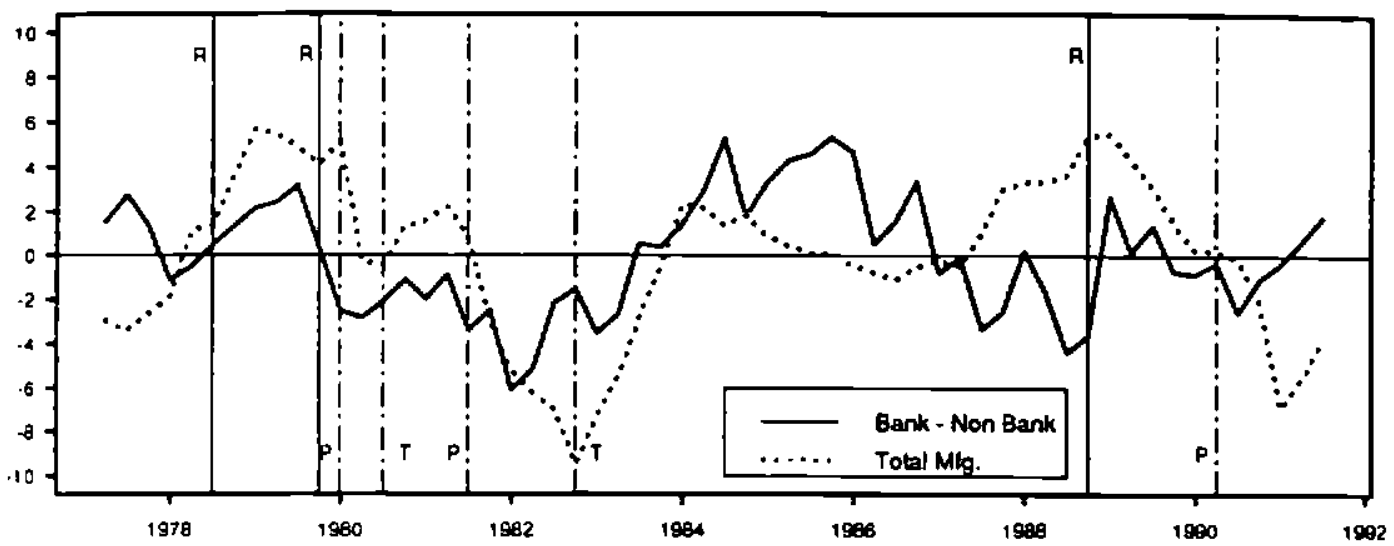

INVENTORIES

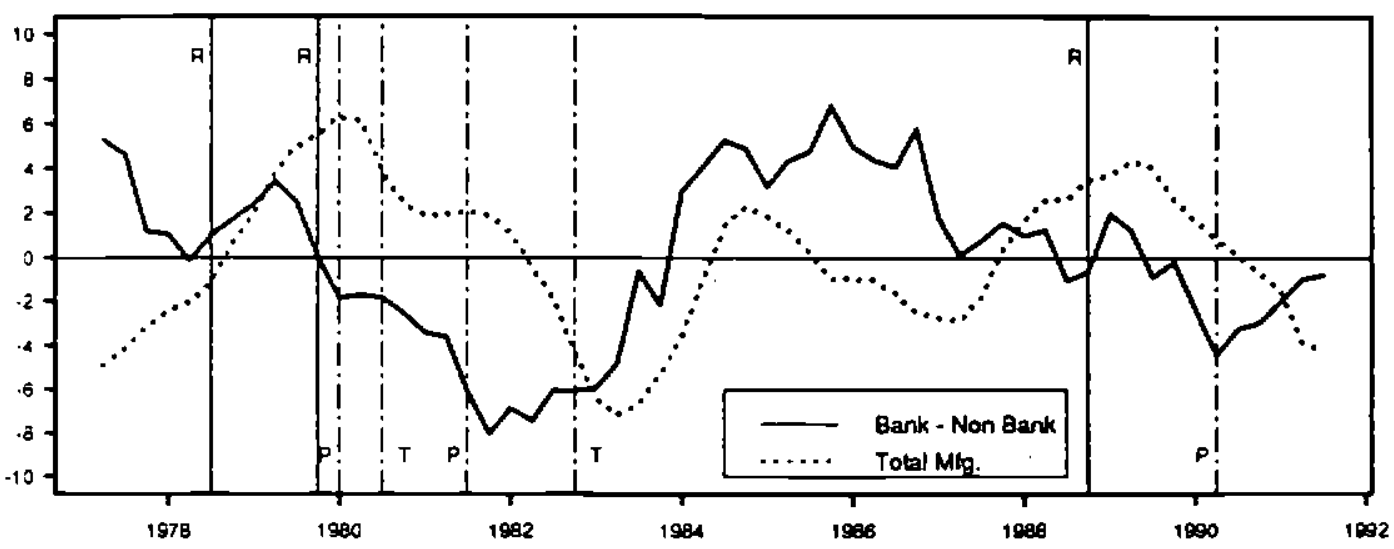

INVENTORIES/SALES

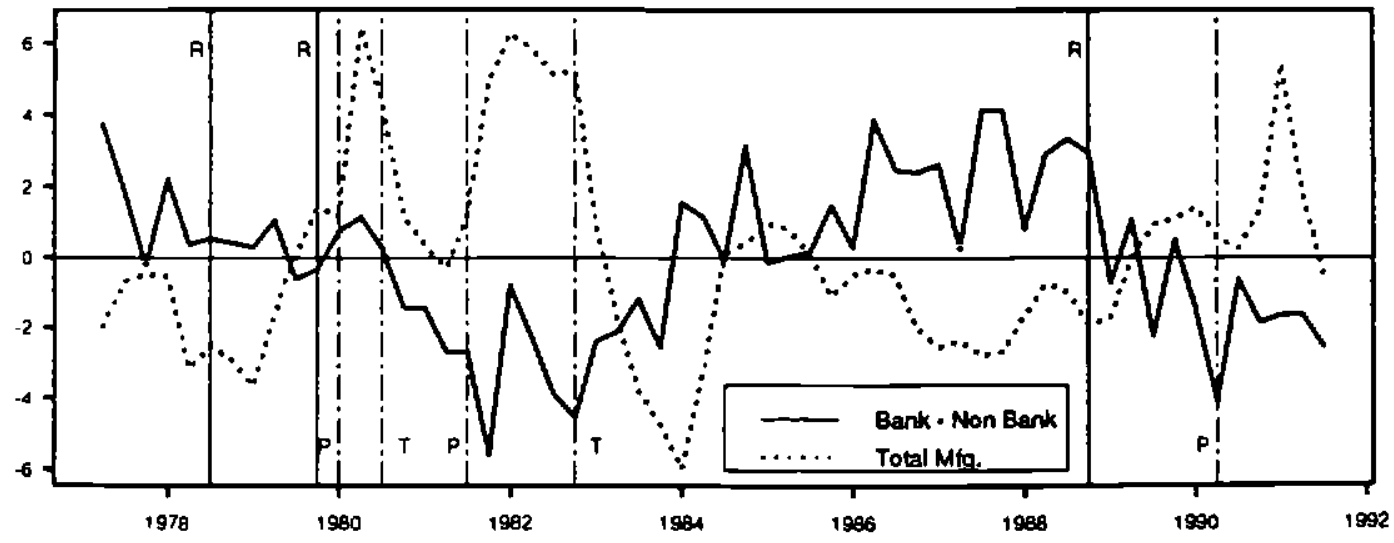




\section{Notes to Figure 5:}

The figure is analogous to Figure 3, except that firms are classifled by "bank-dependency" rather than asset size (see notes to $\mathrm{FIg}_{\mathrm{g}} 4$ or text). Differences in growth rates between bank-dependent and non-bank-dependent firms are industry-adjusted. 